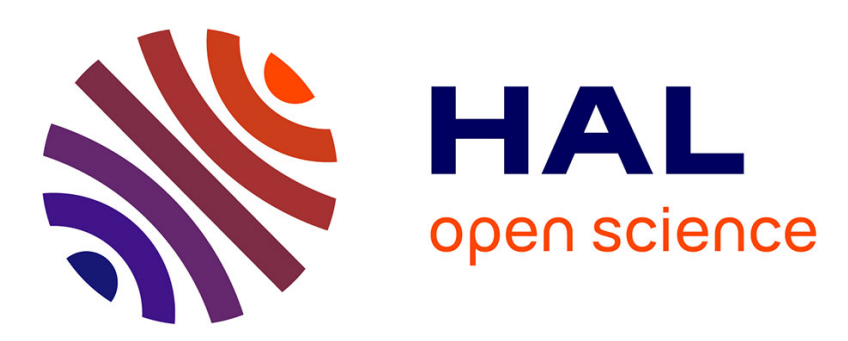

\title{
"Pico- and nanophytoplankton dynamics in two coupled but contrasting coastal bays in the NW Mediterranean Sea (France)"
}

Floriane Delpy, Bruno Serranito, Jean-Louis Jamet, Gérald Grégori, Christophe Le Poupon, Dominique Jamet

\section{To cite this version:}

Floriane Delpy, Bruno Serranito, Jean-Louis Jamet, Gérald Grégori, Christophe Le Poupon, et al.. "Pico- and nanophytoplankton dynamics in two coupled but contrasting coastal bays in the NW Mediterranean Sea (France)". Estuaries and Coasts, In press, 41 (7), pp.2039-2055. 10.1007/s12237018-0412-9 . hal-01783525

\section{HAL Id: hal-01783525 \\ https://hal.science/hal-01783525}

Submitted on 12 Apr 2019

HAL is a multi-disciplinary open access archive for the deposit and dissemination of scientific research documents, whether they are published or not. The documents may come from teaching and research institutions in France or abroad, or from public or private research centers.
L'archive ouverte pluridisciplinaire HAL, est destinée au dépôt et à la diffusion de documents scientifiques de niveau recherche, publiés ou non, émanant des établissements d'enseignement et de recherche français ou étrangers, des laboratoires publics ou privés. 


\title{
Pico- and Nanophytoplankton Dynamics in Two Coupled but Contrasting Coastal Bays in the NW Mediterranean Sea (France)
}

\author{
Floriane Delpy $^{1} \cdot$ Bruno Serranito $^{1}$ - Jean-Louis Jamet ${ }^{1,2} \cdot$ Gérald Grégori $^{3} \cdot$ Christophe Le Poupon $^{1,2}$. \\ Dominique Jamet ${ }^{1,2}$
}

\begin{abstract}
Due to its ecological context, the Toulon bay represents a site of scientific interest to study temporal plankton distribution, particularly pico- and nanophytoplankton dynamics. A monthly monitoring was performed during a two-year cycle (October 2013-December 2015) at two coupled sampling sites, referred to as Little and Large bays, which had different morphometric characteristics and human pressures. Flow cytometry analyses highlighted the fact that pico- and nanophytoplankton were more abundant in the eutrophic Little bay. Furthermore, it evidenced two community structures across the Toulon bays: at times, a co-dominance of picoeukaryotes, nanoeukaryotes, Synechococcus 1-like cells and Prochlorococcus-like cells was found, and at other times, a Synechococcus 1like dominated community existed. The alternation of one structure or the other can be explained by a combined action of temperature regime, nutrient conditions and degree of contamination. This study showed that pico- and nanophytoplankton dynamics were mainly driven by temperature in both sites, as in other temperate Mediterranean regions. Thus, the community was mainly composed of picoeukaryotes and Prochlorococcus-like cells in the winter $\left(<15^{\circ} \mathrm{C}\right)$, while it was dominated by Synechococcus 1-like cells in the summer $\left(>20^{\circ} \mathrm{C}\right)$. Additionally, the multiple human stressors in the Little bay seemed to affect the increase in abundance of Synechococcus 1-like cells as they were preferentially observed in the Large bay.
\end{abstract}

Keywords Pico- and nanophytoplankton $\cdot$ Flow cytometry $\cdot$ Coastal environments $\cdot$ Mediterranean Sea $\cdot$ Spatiotemporal distribution

\section{Introduction}

Picophytoplankton (size $=0.2-2 \mu \mathrm{m}$ ) and nanophytoplankton ( size $=2-20 \mu \mathrm{m})$ constitute an important component of aquatic ecosystems. Pico- and nanophytoplankton contribute up to 43$50 \%$ and $20-32 \%$, respectively, of total primary production

Floriane Delpy

floriane.delpy@univ-tln.fr

$\triangle$ Dominique Jamet

d.jamet@univ-tln.fr

Université de Toulon, Laboratoire PROTEE EA 3819, CS 60584, 83041 Toulon, cedex 09, France

1 Université de Toulon, Aix-Marseille Université, CNRS/INSU, IRD, MIO UM 110, Mediterranean Institute of Oceanography, La

2 Garde, France

Aix-Marseille Université, Université de Toulon, CNRS/INSU, IRD, MIO UM 110, Mediterranean Institute of Oceanography,

3
13288 Marseille, France 
Moran 2011). Furthermore, the size spectrum and species composition of phytoplankton have been identified as indicators of the trophic status in aquatic ecosystems (Bell and Kalff 2001; Bosak et al. 2012).

Pico- and nanophytoplankton populations exhibit an autofluorescence induced by their photosynthetic pigments (e.g. chlorophyll $a$, phycoerythrin, phycocyanin) that can be detected by analytical flow cytometry (Yentsch et al. 1983; Yentsch and Horan 1989). This method performs single-cell analysis at high frequency (up to several thousand cells are analyzed per second) and has been widely used to investigate the spatiotemporal distribution of these organisms (Marie et al. 1997; Dubelaar and Jonker 2000; Veldhuis and Kraay 2000). As water samples are analyzed at the single cell level, each cluster of pico- or nanophytoplankton can be differentiated thanks to its optical properties (i.e. types and intensities of fluorescence).

Pico- and nanophytoplanktonic microorganisms are particularly sensitive to external forcing, inducing changes in composition, abundance, cell size and pigment content at an hourly scale (Dugenne et al. 2014; Thyssen et al. 2014). Under specific conditions, they can have faster cell cycles with higher growth rates. Thus, in the presence of warm and nutrient-poor waters, picophytoplankton is the main contributor to the total phytoplankton production in the Mediterranean Sea (Agawin et al. 2000). The composition of pico- and nanophytoplankton communities is influenced by fundamental physico-chemical factors that are characteristic of their environments (e.g. temperature, salinity, nutrients) (Moisan et al. 2010; Amorim et al. 2016). These factors vary naturally (e.g. depending on the season, rainfall, wind) or can be influenced by human pressures (e.g. massive inputs of freshwater from power plants, byproducts from wastewater treatment plants). Therefore, pico- and nanophytoplanktonic groups may be considered as good biosensors and even as good bioindicators of water quality, especially directly or indirectly in coastal ecosystems affected by various human activities (Grégori et al. 2001; Caroppo et al. 2006).

Reports of studies in the Northwestern part of the Mediterranean Sea, an area particularly influenced by anthropogenic constraints (Karydis and Kitsiou 2012), are still scarce in the literature due to the lack of ultraplankton monitoring compared to other oceanic regions (Denis et al. 2000; Grégori et al. 2001; Goffart et al. 2015). On the French Mediterranean coast, the Toulon bay represents a site of special scientific interest in the Marine Strategy Framework Directive (MSFD, European Commission) and in the French national network RESOMAR (REseaux des Stations et Observatoires MARins) (Serranito et al. 2016). Its functioning is determined by typical climatic conditions observed in this temperate Mediterranean region, with large intra-annual variations of temperature. Influenced by inputs from Toulon city (ca. 170,000 inhabitants), this site is composed of two systems known as Little bay and Large bay, which are separated by a breakwater built in 1882. Previous studies highlighted that both sites are affected by various human pressures. The Little bay is a semi-enclosed ecosystem affected by many human activities (i.e. commercial and military harbors, industries, shipyard), as well as by natural inputs from the Las River and the Large bay (Tessier et al. 2011; Pougnet et al. 2014). Conversely, the Large bay waters are influenced by the North current and, to a lesser extent, by an outfall pipe of a wastewater treatment plant and occasional freshwater inputs from the Eygoutier River (Jouan et al. 2001; Nicolau et al. 2006). Some planktonic compartments observed in the Toulon bays, such as microphytoplankton and zooplankton, have been the subject of many studies (Jamet et al. 2001; Rossi and Jamet 2009; Serranito et al. 2016). These communities appeared to be more abundant but less diversified in the Little bay than in the Large bay. Microphytoplankton was investigated and blooms evidenced in the area had a typical pattern of temperate marine regions, reaching their highest densities in the spring and occasionally in the autumn (Rossi 2008). Some phytotoxic species, such as Alexandrium and Dinophysis, were regularly observed (Belin and Raffin 1998; Joanny et al. 1993). There is no information available concerning ultraphytoplankton (cell size $<10 \mu \mathrm{m}$; Strickland 1965). In this context, the present work complements previous studies, by focusing on the understudied pico- and nanophytoplankton compartments. The main objectives are (a) to evaluate how multiple human stressors influenced pico- and nanophytoplankton communities in coastal environments and (b) to identify which main environmental variables drove their phenology. Spatial and temporal variabilities of the picoand nanophytoplankton communities are expected in relation to the different human pressures observed in coastal areas and to large temperature variations typical of temperate regions.

\section{Material and Methods}

\section{Study Sites}

Located on the French Mediterranean coast $\left(43^{\circ} 05^{\prime} \mathrm{N} / 05^{\circ} 55^{\prime}\right.$ E), Toulon bay consists of two contrasting systems, the Little bay and the Large bay, separated by an artificial breakwater $1.4 \mathrm{~km}$ long and $3 \mathrm{~m}$ wide (Fig. 1). The Little bay is a semienclosed basin of $9.8 \mathrm{~km}^{2}$ (mean depth of $15 \mathrm{~m}$ ) (Dang et al. 2014), whereas the Large bay is more open to the sea $\left(42 \mathrm{~km}^{2}\right.$, 5 to $30 \mathrm{~m}$ deep). These two sites only communicate by two passes: a small one at the north of the breakwater $(30 \mathrm{~m}$ wide, $10 \mathrm{~m}$ deep) and a larger pass at the south $(\sim 1 \mathrm{~km}$ wide, maximum depth of $30 \mathrm{~m}$ ) which constitutes the shipping channel.

They are submitted to the same typical climatic conditions of temperate Mediterranean regions, with two prevailing 


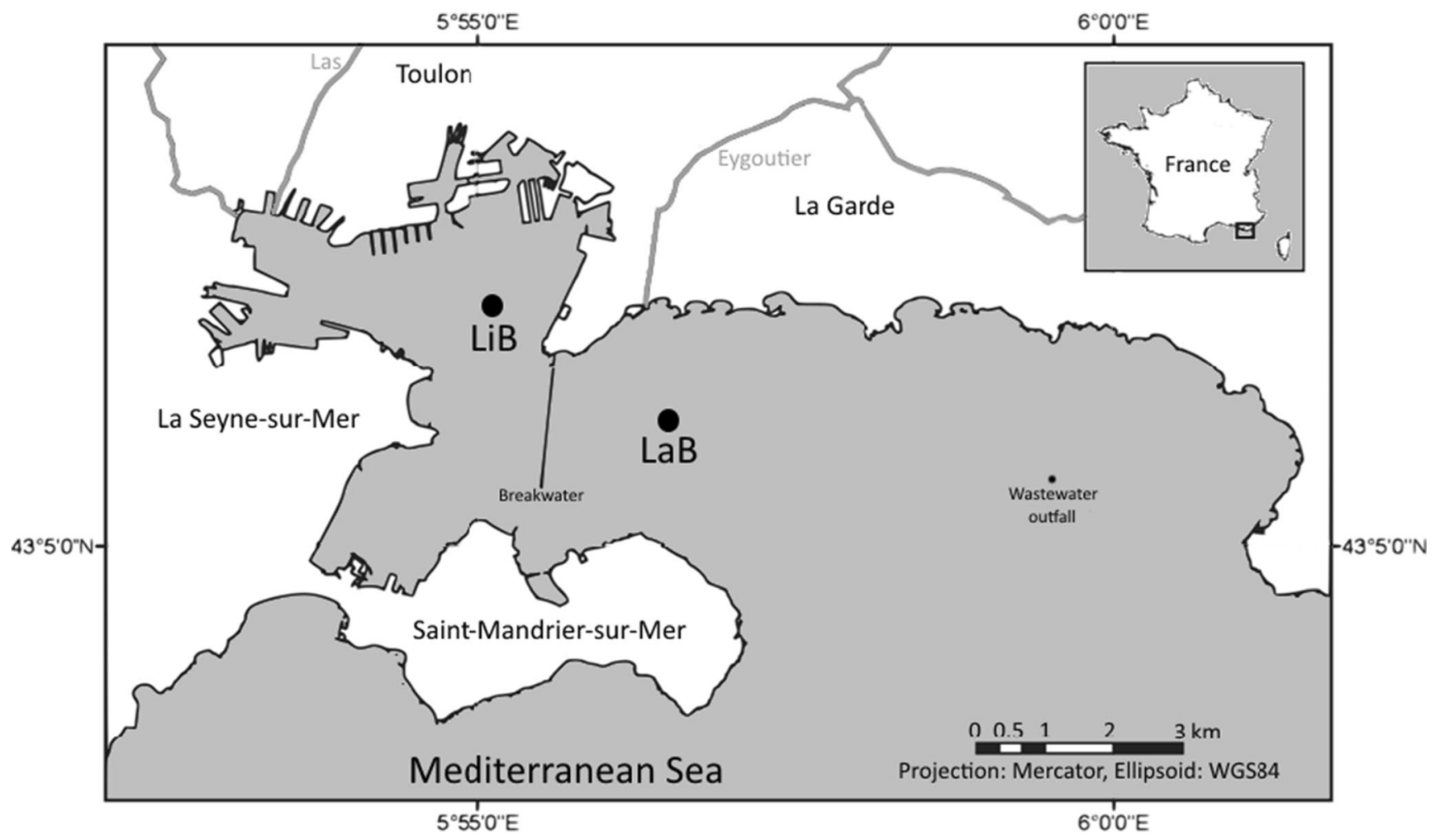

Fig. 1 Map of Toulon bay, and location of the two sampled stations: LiB (Little bay) and LaB (Large bay)

winds, i.e. the Mistral (W-NW) and a South-East wind. Hydrodynamic models of the Toulon bay showed that water circulation is directly driven by wind events inducing sediment resuspension (Jouan et al. 2001; Dufresne et al. 2014). Without any wind, water circulation is much less active, since then only the constant North current generates a cyclonic circulation of the order of a few centimetres per second (Tessier et al. 2011; Dufresne et al. 2014). The water residence time was from 3 to 6 days in the Little bay and about 1-2 days in the Large bay (Jouan et al. 2001; Duffa et al. 2011).

A monthly sampling was carried out from October 2013 to December 2015 at two stations: one in the Little bay (LiB, $43^{\circ} 06^{\prime} 30^{\prime \prime} \mathrm{N} / 05^{\circ} 55^{\prime} 00^{\prime \prime} \mathrm{E}, 12 \mathrm{~m}$ deep) and one in the Large bay (LaB, $43^{\circ} 05^{\prime} 45^{\prime \prime} \mathrm{N} / 05^{\circ} 56^{\prime} 40^{\prime \prime}$ E, $17 \mathrm{~m}$ deep) (Fig. 1). All samples were collected between 08:00 and 10:00 h.

\section{Environmental Parameters}

Temperature, salinity (conductivity) and dissolved oxygen concentration were measured in the Little and Large bays at 3 and $10 \mathrm{~m}$ depths with a calibrated multiparametric probe (Hydrolab-Quanta). Concentrations of nitrite/nitrate (N$\left.\mathrm{NO}_{\mathrm{x}}{ }^{-}=\mathrm{NO}_{2}{ }^{-}+\mathrm{NO}_{3}{ }^{-}\right)$and reactive phosphorus $\left(\mathrm{P}^{-} \mathrm{PO}_{4}{ }^{3-}\right)$ were also measured in 2015. Water samples were collected at 3 and $10 \mathrm{~m}$ depths in both sites, with a 10-L Niskin bottle, then transferred into 50-mL polypropylene centrifuge tubes and immediately frozen at $-20{ }^{\circ} \mathrm{C}$ until further analysis (Clementson and Wayte 1992; Dore et al. 1996). All reagents were at least of analytical grade. Reagent solutions were prepared in distilled-deionized water (Millipore, Milli-Q system) and used as diluent for all reagents and to establish the baseline. Nitrite/nitrate analyses $\left(\mathrm{N}_{-} \mathrm{NO}_{\mathrm{x}}{ }^{-}\right.$thereafter) were performed using a continuous flow Technicon Autoanalyzer II system, following the method by Tréguer and Le Corre (1975). These autoanalyses have a detection limit of $0.03 \mu \mathrm{M}$ and an approximate analytical precision of $\pm 0.3 \%$. Reactive phosphorus in seawater determination is based on the method by Murphy and Riley (1962), with modifications of Strickland and Parsons (1968). The resulting complex gives a blue-colored solution, and its absorbance can be measured with a spectrophotometer (UV-1800, Shimadzu) at a wavelength of $885 \mathrm{~nm}$ in a 10-cm cell, against a blank of Milli-Q water. These analyses have a detection limit of $0.02 \mu \mathrm{M}$ and an approximate analytical precision of $\pm 0.5 \%$.

\section{Pico- and Nanophytoplankton}

\section{Sampling}

To determine the abundance of pico- and nanophytoplankton, water samples were collected with a 10-L Niskin bottle at 3 and $10 \mathrm{~m}$ depths in both sites ( $\mathrm{LiB}$ and $\mathrm{LaB})$. Samples were first filtered through a $90-\mu \mathrm{m}$ mesh to eliminate grazers and macroparticles (i.e. debris). Sub-samples of $4.5 \mathrm{~mL}$ were then immediately fixed with a glutaraldehyde solution (final concentration at $0.25 \%$ ), incubated for $15 \mathrm{~min}$ in the dark and 
flash-frozen in liquid nitrogen. These sub-samples were thawed at $37{ }^{\circ} \mathrm{C}$ just prior to analysis by flow cytometry.

\section{Flow Cytometry Analyses}

Flow cytometry analyses were performed using an Accuri C6 flow cytometer (BD Biosciences) equipped with 488 and $640 \mathrm{~nm}$ laser beams. Ultrapure water filtered through a $0.2-\mu \mathrm{m}$ filter was used as the sheath fluid. For each particle analyzed, two light scattering intensities were collected: the forward scattered light (FSC) is related to the size of the particles, while the side scattered light (SSC) is related to their shape and inner structure. Three natural fluorescence intensities induced by the $488 \mathrm{~nm}$ laser beam were recorded. The flow cytometer measured red fluorescence (FL3) mainly emitted by chlorophyll $(>670 \mathrm{~nm}$ ), orange fluorescence (FL2) mainly resulting from phycoerythrin emission $(585 \pm 20 \mathrm{~nm})$ and green fluorescence (FL1) $(530 \pm 15 \mathrm{~nm})$. The FL4 far red fluorescence $(675 / 25 \mathrm{~nm})$ is induced by the $640-\mathrm{nm}$ red laser beam. It is worth noting that the abundance of the smallest cells, especially cyanobacteria, can be underestimated with a BD Accuri C6 because of their low content of photosynthetic pigments and only partially solved from background noise (Ribeiro et al. 2016). Beads of $2 \mu \mathrm{m}$ diameter (Fluoresbrite YG, Polysciences) were periodically added to the samples as an internal standard. All data were collected on a log scale using CFlowPlus software (BD Biosciences). A total of $500 \mu \mathrm{L}$ sub-samples were analyzed at a flow rate of $60 \mu \mathrm{L} \min ^{-1}$. Data acquisition was triggered using the red fluorescence signal to focus on autofluorescent particles containing chlorophyll $a$ (i.e. pico- and nanophytoplankton). The optical resolution of the various clusters was based on their ranges of light scattering and fluorescence intensities using two-dimensional data displays called cytograms (Olson et al. 1993; Marie et al. 2001, 2014). Median values were used to describe the optical characteristics of each group.

\section{Statistical Analyses}

As data were not normally distributed (Shapiro-Wilk test), non-parametric Mann-Whitney $U$ tests (MWU thereafter; Mann and Whitney 1947) were used to estimate the effect of sampling sites (depth or station) on environmental parameters (temperature, salinity, dissolved oxygen, $\mathrm{N}_{-} \mathrm{NO}_{\mathrm{x}}{ }^{-}$and $\mathrm{P}-\mathrm{PO}_{4}{ }^{3-}$ concentrations) and on communities studied (pico- and nanophytoplankton abundance, fluorescence intensities). Sampling sites were considered independent of each other. Therefore, as no significant difference was recorded between 3 and $10 \mathrm{~m}$ depths $(p>0.05)$, abiotic data, pico- and nanophytoplankton abundance and fluorescence intensities were averaged. These statistical analyses were performed using Statistica 7.1 (StatSoft, Inc.). The relationships between the temporal variations observed in the Little bay and those observed in the Large bay were examined for total pico- and nanophytoplankton abundance and for each cluster using Pearson correlation analyses ( $R$ software).

A PERmutational Multivariate ANalysis Of VAriance (PERMANOVA) was conducted on Bray-Curtis distances to evaluate the impact of the site ( $\mathrm{LiB}$ and $\mathrm{LaB}$ ), the season and the year on the structure of pico- and nanophytoplankton communities, using the "Vegan" package of R software (Anderson 2001). For each site, the linear relationship between pico- and nanophytoplankton groups and environmental conditions was evaluated on data from 2015, using constrained analysis (Redundancy Analysis) on an exploratory matrix (standardized abiotic data) and response data (logtransformed abundance). The evaluation of global analysis and factor significance was performed according to stepwise model selection using a 1000 permutation test ("Ordistep" function from the "Vegan" package of $\mathrm{R}$ software). Results were summarized in triplot ordination and represented in scaling 2 so that the angles of the different vectors corresponded to an approximation of the correlations observed between the variables. Finally, two-dimensional surface plots were drawn to show the effects of temperature and salinity on the abundance of the pico- and nanophytoplankton groups using pooled datasets of the Little and Large bays. They were then summarized by a global analysis on the total pico- and nanophytoplankton assemblage. These kriging analyses were performed with a linear variogram model using Surfer 11 (Golden Software).

\section{Results}

\section{Hydrological Parameters}

Seasonal variations of the hydrological variables, i.e. temperature, salinity, dissolved oxygen, $\mathrm{N}-\mathrm{NO}_{\mathrm{x}}{ }^{-}$and $\mathrm{P}-\mathrm{PO}_{4}{ }^{3-}$ concentrations, are displayed in Fig. 2. Similar ranges of temperature were observed in the Little bay $(\mathrm{LiB})$ and Large bay (LaB): 13.1 to $23.1{ }^{\circ} \mathrm{C}$ and 12.9 to $23.0{ }^{\circ} \mathrm{C}$, respectively (Fig. 2a). Maximal values were recorded in the summer or early autumn and minimal ones in the winter, corresponding to typical seasonal variations observed in the temperate Mediterranean areas. Nevertheless, a delay in the warm season was evidenced, with the highest temperatures $\left(>22{ }^{\circ} \mathrm{C}\right)$ observed from September to October 2014 and from June to August 2015. The coldest period $\left(<13{ }^{\circ} \mathrm{C}\right)$ only lasted one month in 2014 (February) and three months in 2015 (January to March). 


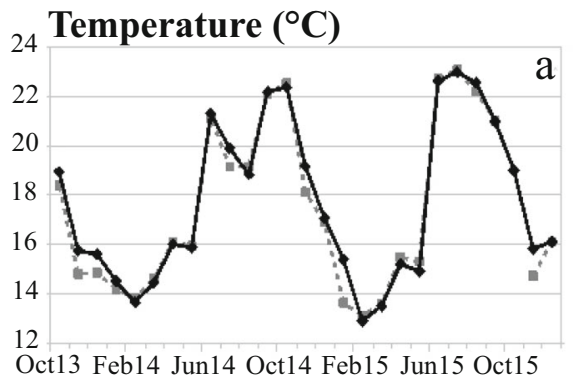

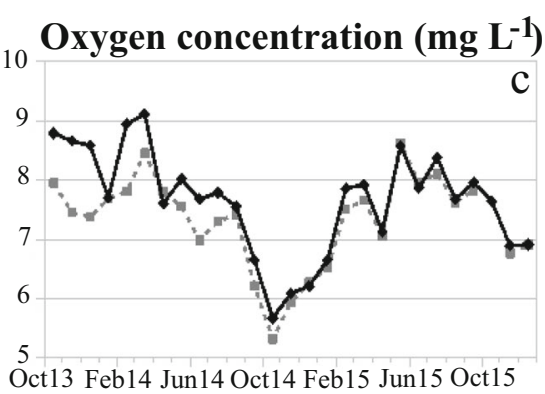
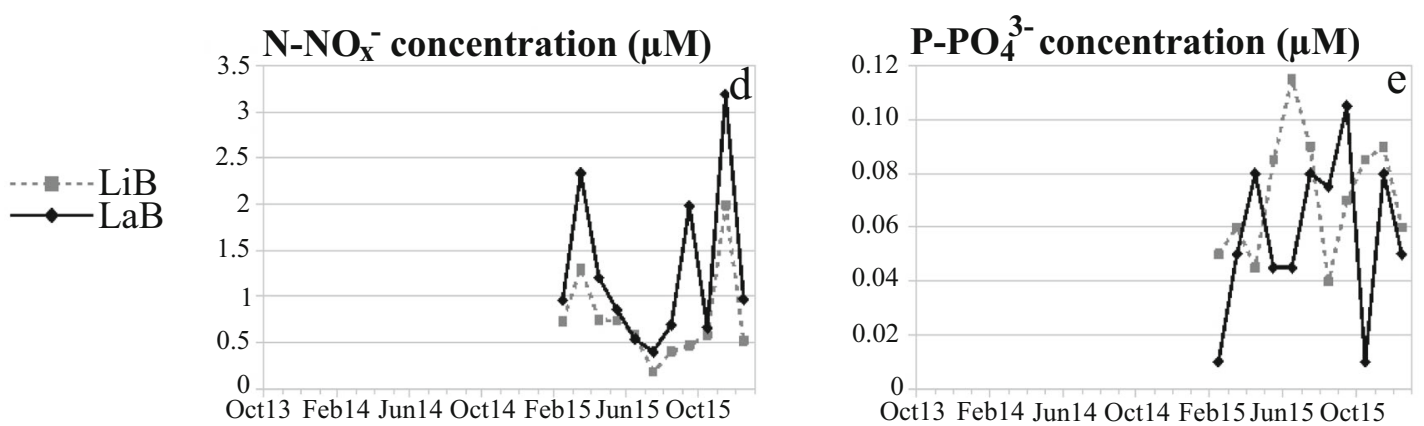

Fig. 2 Temporal variations of temperature $\left({ }^{\circ} \mathrm{C}\right)(\mathbf{a})$, salinity $(\mathbf{b})$, dissolved oxygen $\left(\mathrm{mg} \mathrm{L}^{-1}\right)(\mathbf{c}), \mathrm{N}^{-\mathrm{NO}_{\mathrm{x}}}{ }^{-}(\mu \mathrm{M})(\mathrm{d})$ and $\mathrm{P}-\mathrm{PO}_{4}{ }^{3-}(\mu \mathrm{M})(\mathbf{e})$ concentrations for $\mathrm{LiB}$ and $\mathrm{LaB}$. Data were averages of that obtained at depths of 3 and $10 \mathrm{~m}$

Salinity was similar to that observed in the coastal areas of the Northwestern Mediterranean basin, with mean values of $37.7 \pm 1.2$ in $\mathrm{LiB}$ and $37.8 \pm 1.1$ in LaB (Fig. 2b). For both sites, exceptional highest values $(\sim 39.7)$ were recorded in October 2014, whereas the lowest ones ( 35.6) were observed in February-March 2014. No data was recorded from May to July 2015 because of a dysfunction of the sensor.

Dissolved oxygen concentrations varied from 5.3 to $9.1 \mathrm{mg} \mathrm{L}^{-1}$ with minimal values seen between September 2014 and January 2015 (Fig. 2c). Oxygen concentrations were significantly different between the two sites, with higher values in $\mathrm{LaB}\left(7.6 \pm 0.9 \mathrm{mg} \mathrm{L}^{-1}\right)$ than in $\mathrm{LiB}\left(7.3 \pm 0.8 \mathrm{mg} \mathrm{L}^{-1}\right)(\mathrm{MWU}, p<0.05)$.

Nutrients were not analyzed in the first year of this study. However, $\mathrm{N}-\mathrm{NO}_{\mathrm{x}}{ }^{-}$and $\mathrm{P}-\mathrm{PO}_{4}{ }^{3-}$ concentrations were measured in 2015. $\mathrm{N}^{-\mathrm{NO}_{\mathrm{x}}}{ }^{-}$concentrations had major variations $(0.4$ to $3.2 \mu \mathrm{M})$ with maximal values $(>1 \mu \mathrm{M}$ in $\mathrm{LiB}$ and $>2 \mu \mathrm{M}$ in LaB) displayed in March, September and November 2015 (Fig. 2d). As for dissolved oxygen, N$\mathrm{NO}_{\mathrm{x}}{ }^{-}$concentrations were significantly higher in LaB (1.2 $\pm 0.9 \mu \mathrm{M})$ than in $\mathrm{LiB}(0.7 \pm 0.5 \mu \mathrm{M})$ (MWU, $p<0.05)$. Considering $\mathrm{P}_{-} \mathrm{PO}_{4}{ }^{3-}$ concentration, no significant difference in the average was highlighted between the two sites (MWU, $p>0.05$ ) (Fig. 2e). Nevertheless, LiB exhibited two lower values $(<0.05 \mu \mathrm{M})$ and five upper values $(>$ $0.08 \mu \mathrm{M})$, whereas $\mathrm{LaB}$ displayed five lower values $(<$ $0.02 \mu \mathrm{M}$ ) and three upper values (twice about $0.08 \mu \mathrm{M}$ and once $>0.1 \mu \mathrm{M}$ ). The median values illustrate more clearly the differences between the sites with $0.07 \mu \mathrm{M}$ for $\mathrm{LiB}$ and $0.05 \mu \mathrm{M}$ for $\mathrm{LaB}$, showing that $\mathrm{LiB}$ is generally more concentrated in $\mathrm{P}_{-} \mathrm{PO}_{4}{ }^{3-}$ during the period studied.

\section{Time Series of Pico- and Nanophytoplankton Groups as Defined by Flow Cytometry}

Five different clusters of pico- and nanophytoplankton were discriminated by flow cytometry thanks to their optical properties: Synechococcus-like (SYN), Prochlorococcus-like (PROCHL), picoeukaryotes (PICOEuk), nanoeukaryotes (NANOEuk) and Cryptophyceae (CRYPTO) (Fig. 3). As we did not include any molecular biology approach to identify the species present in the area, we used the term "like" to characterize cyanobacteria. Typical flow cytometric signatures based on both light scattering and fluorescence intensities were used to define each cluster (Olson et al. 1993; Marie et al. 2001). The analysis of these signatures showed that Synechococcuslike was composed of two sub-clusters defined by different optical characteristics: Synechococcus 1-like (SYN1) and Synechococcus 2-like (SYN2). Cyanobacteria (PROCHL and SYN) were the smallest cells $(\mathrm{FSC}<11,000)$, followed by PICOEuk $(\sim 43,000)$, NANOEuk $(\sim 413,000)$ and CRYPTO $(\sim 913,000)$. This order was confirmed with the SSC. Considering fluorescence, SYN1 cells were obviously richer in orange fluorescence (FL2) due to the phycoerythrin presence, whereas the chlorophyll $a$-related red fluorescence (FL3) is dominant for the other four groups. PROCHL had the lowest intensities for the two red fluorescences (FL3 and FL4). PICOEuk, NANOEuk and CRYPTO exhibited an increased red FL3 fluorescence intensity according to their size. CRYPTO were also discriminated from other NANOEuk thanks to their higher orange fluorescence intensity (FL2). Another population was observed during this monitoring 

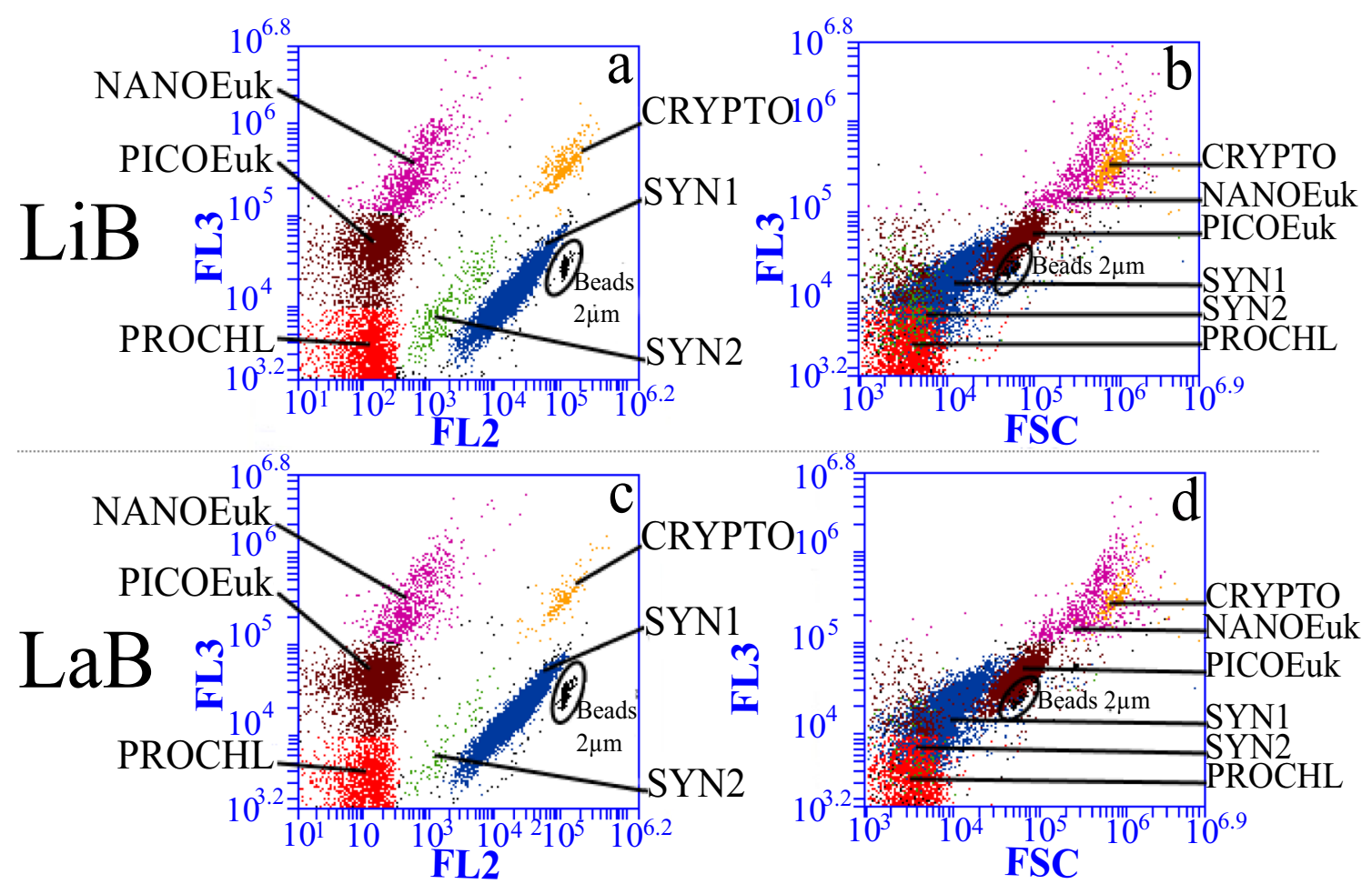

Fig. 3 Cytograms of orange (FL2) vs. red (FL3) fluorescence intensities in parts a and c. Cytograms of size (FSC) vs. red fluorescence intensity (FL3) in parts b and $\mathbf{d}$. Data corresponded to two natural water samples collected in December 2014 in $\mathrm{LiB}$ (a and b) and $\mathrm{LaB}$ (c and d) at a depth

and was referred to as SYN2. These cells had a transitional orange fluorescence intensity between that of PROCHL and of SYN1, as well as similar red fluorescence and FSC signals to those of cyanobacteria. SYN1 and SYN2 could be different clades (unchecked hypothesis by genetic analysis), but also cells in different physiological state (alive or dying cells).

Pico-and nanophytoplankton abundance in the Toulon bays is displayed in Fig. 4. From October 2013 to December 2015, total abundance showed significant positive correlation between the two sites as shown by Pearson correlation tests $(r=0.42, p=0.02)$ (Fig. 4a). Comparable timing of maximal values was observed in November $2013\left(51,996\right.$ cells $\mathrm{mL}^{-1}$ in LiB vs. 43,056 cells $\mathrm{mL}^{-1}$ in LaB), in February 2014 (34,493 cells $\mathrm{mL}^{-1}$ in LiB vs. 36,631 cells $\mathrm{mL}^{-1}$ in $\left.\mathrm{LaB}\right)$, in June 2014 (42,689 cells $\mathrm{mL}^{-1}$ in LiB vs. 39,196 cells $\mathrm{mL}^{-1}$ in LaB) and in February 2015 (50,629 cells $\mathrm{mL}^{-1}$ in LiB vs. 37,615 cells $\mathrm{mL}^{-1}$ in $\left.\mathrm{LaB}\right)$. Nevertheless, in autumn 2014 and spring-summer 2015, three peaks occurred slightly later in LiB (October-November 2014, May and August 2015) than in LaB (September-October 2014, April and July 2015). Furthermore, the range of total abundance was shifted towards higher values in $\mathrm{LiB}$ which displayed one minimum value $\left(<20,000\right.$ cells $\left.\mathrm{mL}^{-1}\right)$ and six maximum ones $(>$ 40,000 cells $\left.\mathrm{mL}^{-1}\right)$, than in $\mathrm{LaB}$ that exhibited eight minimum values and only four maximum ones.

Strong positive correlations were also highlighted between the temporal variations observed in $\mathrm{LiB}$ and $\mathrm{LaB}$ for

of $3 \mathrm{~m}$. Abbreviations: SYN1, Synechococcus 1-like; PROCHL, Prochlorococcus-like; PICOEuk, picoeukaryotes; NANOEuk, nanoeukaryotes; CRYPTO, Cryptophyceae; SYN2, Synechococcus 2like

PROCHL, SYN2, PICOEuk and NANOEuk (Pearson correlation tests, $r=0.68, r=0.74, r=0.62, r=0.51$, respectively, with $p<0.01)$. At both sites, the lowest abundance of PROCHL occurred in the summer $\left(1829 \pm 768\right.$ cells $\mathrm{mL}^{-1}$ in $\mathrm{LiB}$ vs. $529 \pm 354$ cells $\mathrm{mL}^{-1}$ in $\left.\mathrm{LaB}\right)$ and the highest ones in late autumn-winter $\left(5160 \pm 2901\right.$ cells $\mathrm{mL}^{-1}$ in LiB vs. 3348 \pm 1749 cells $\mathrm{mL}^{-1}$ in $\mathrm{LaB}$ ) (Fig. 4c). The abundance of SYN2 did not exhibit a clear seasonal pattern with maximal values recorded in September 2014 (659 cells $\mathrm{mL}^{-1}$ in $\mathrm{LiB}$ vs. 435 cells $\mathrm{mL}^{-1}$ in LaB) (Fig. 4d). Concerning PICOEuk, the highest abundance was observed in February 2014 (13,630 cells $\mathrm{mL}^{-1}$ in LiB vs. 14,711 cells $\mathrm{mL}^{-1}$ in LaB) and in February 2015 (29,602 cells $\mathrm{mL}^{-1}$ in LiB vs. 19,645 cells $\mathrm{mL}^{-1}$ in LaB) (Fig. 4e). It is worth noting that two autumnal peaks also occurred in LiB in November 2013 $\left(26,978 \pm 1448\right.$ cells $\left.\mathrm{mL}^{-1}\right)$ and in November $2014(16,966 \pm$ 6771 cells $\left.\mathrm{mL}^{-1}\right)$. NANOEuk were particularly abundant in June and October (Fig. 4f).

Conversely, an absence of correlation was identified between the two sites for the two remaining groups: SYN1 and CRYPTO (MWU, $p>0.05$ ). The highest abundance of SYN1 (defined as $>30,000$ cells $\mathrm{mL}^{-1}$ ) was recorded in SeptemberOctober $2014\left(39,679 \pm 4953\right.$ cells $\left.\mathrm{mL}^{-1}\right)$ and in April 2015 $\left(42,917 \pm 1079\right.$ cells $\left.\mathrm{mL}^{-1}\right)$ in $\mathrm{LaB}$, while a single peak occurred in July-August $2015\left(32,396 \pm 2021\right.$ cells $\left.\mathrm{mL}^{-1}\right)$ in LiB (Fig. 4b). Maximal values of CRYPTO were found in 

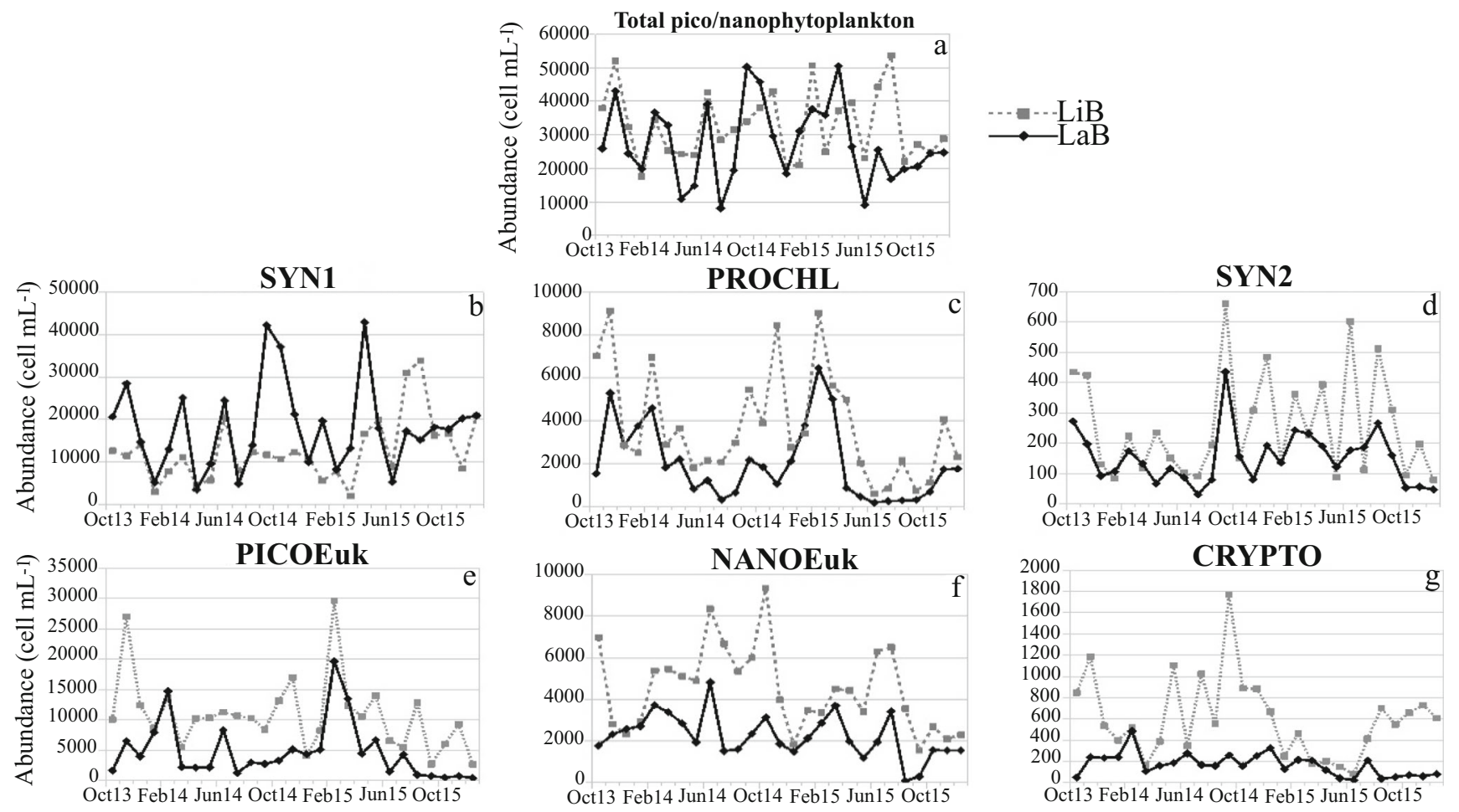

Fig. 4 Temporal variations of abundance (cells $\mathrm{mL}^{-1}$ ) for total pico- and nanophytoplankton (a) and each identified cluster (b to $\left.\mathbf{g}\right)$ in LiB and LaB. Data were averages of that obtained at depths of 3 and $10 \mathrm{~m}$

summer-early autumn in LiB, whereas no clear seasonal pattern was detected in $\mathrm{LaB}$ (Fig. $4 \mathrm{~g}$ ).

The differences in the abundance of pico- and nanophytoplankton between the two sites were confirmed as shown in Fig. 5. Total abundance of pico- and nanophytoplankton were significantly different between the two sites studied, with a higher median value in $\mathrm{LiB}$ $\left(31,280\right.$ cells $\left.\mathrm{mL}^{-1}\right)$ than in $\mathrm{LaB}\left(25,122\right.$ cells $\left.\mathrm{mL}^{-1}\right)$ (MWU, $p<0.05$ ) (Fig. 5a). A similar spatial distribution was observed for almost all groups: PROCHL (2892 cells $\mathrm{mL}^{-1}$ in LiB vs. 1668 cells $\mathrm{mL}^{-1}$ in LaB), PICOEuk (10,239 cells mL $\mathrm{mL}^{-1}$ in LiB vs. 2930 cells $\mathrm{mL}^{-1}$ in LaB), SYN2 (181 cells $\mathrm{mL}^{-1}$ in $\mathrm{LiB}$ vs. 142 cells $\mathrm{mL}^{-1}$ in LaB), NANOEuk (4424 cells mL ${ }^{-1}$ in LiB vs. 2078 cells $\mathrm{mL}^{-1}$ in $\mathrm{LaB}$ ) and CRYPTO (552 cells $\mathrm{mL}^{-1}$ in $\mathrm{LiB}$ vs. 152 cells $\mathrm{mL}^{-1}$ in $\left.\mathrm{LaB}\right)(p<0.05)$ (Fig. $5 \mathrm{c}-$ g). Only SYN1 were significantly more abundant in LaB $\left(16,732\right.$ cells $\left.\mathrm{mL}^{-1}\right)$ than in $\mathrm{LiB}\left(11,467\right.$ cells $\left.\mathrm{mL}^{-1}\right)(\mathrm{MWU}$, $p<0.05)$ (Fig. 5a).

Besides the abundance of cells, the fluorescence intensities of both photosynthetic pigments characterizing the populations of Toulon bay (chlorophyll $a$ and phycoerythrin) were then investigated. Inter-annual variations of these features can reflect photoacclimation, blooms of small cells or a shift in species (DuRand et al. 2001; Mella-Flores et al. 2012). The intensity of chlorophyll $a$-related red fluorescence displayed clear seasonal variations for four groups: SYN1, PICOEuk, NANOEuk and CRYPTO (Fig. 6). The highest values were observed in the winter, whereas the lowest ones corresponded to summer periods. The same seasonal pattern was observed for the intensity of phycoerythrin-related orange fluorescence, which was characteristic of SYN1 and CRYPTO. It is worth noting that NANOEuk gave significantly higher red fluorescence values in $\mathrm{LiB}(237,462 \pm 94,194)$ than in $\mathrm{LaB}(173,473$ $\pm 71,721)$ (MWU, $p<0.05$ ).

\section{Driving Factors of the Pico- and Nanophytoplankton Structure}

A PERMANOVA analysis was performed to determine the influence of the sites ( $\mathrm{LiB}$ or $\mathrm{LaB}$ ), the seasons and the years on the structure of the pico- and nanophytoplankton community (Table 1). The factor "Site" explained most of the variance $\left(R^{2}=17.9 \%\right)$, followed by the factor "Season" $\left(R^{2}=15.2 \%\right)$. The factor "Year" was slightly significant, at $3.3 \%$ of the variance. Two interactions involving the seasons were also significant: "Season" and "Year" $(8.1 \%)$ and "Site" and "Season" (3.9\%).

The relative contribution of pico- and nanophytoplankton groups highlighted similar seasonal patterns of abundance at both sites but with different intensities, as shown in Fig. 7. In $\mathrm{LiB}, \mathrm{SYN} 1$ were predominant in the summer-autumn for both years $(48.0 \pm 17.4 \%)$, whereas the community was dominated by PICOEuk $(42.8 \pm 12.5 \%)$ and SYN1 $(22.5 \pm 12.2 \%)$ in the winter. In LaB, SYN1 dominated the community with $74.1 \pm$ 

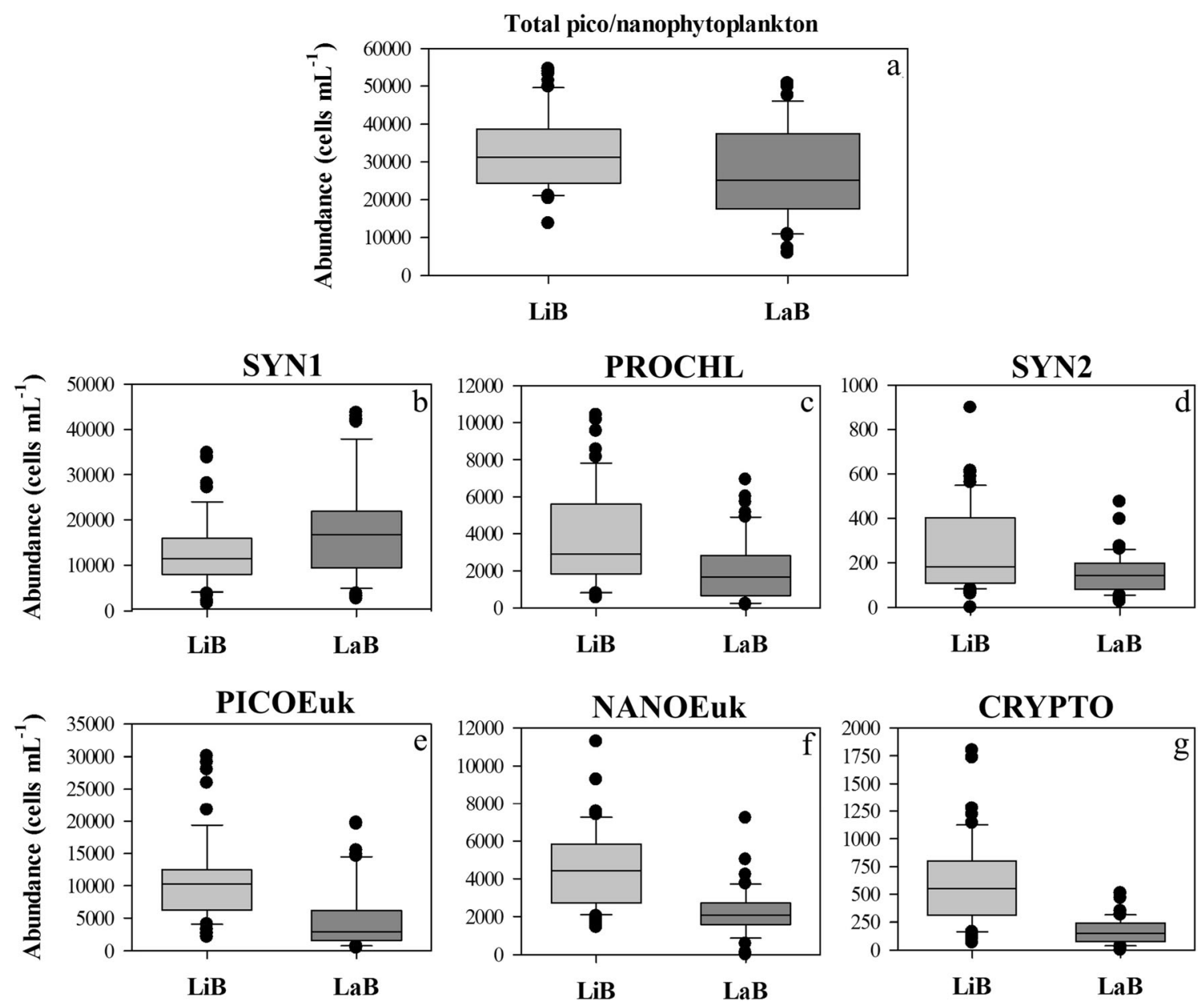

Fig. 5 Abundance (cells $\mathrm{mL}^{-1}$ ) of total pico- and nanophytoplankton (a) and of each identified cluster (b to $\mathbf{g}$ ) in $\mathrm{LiB}$ and $\mathrm{LaB}$. The central boxes show the data between the 25 th and the 75 th percentiles with the median

represented as a line. The whiskers extend to the 10th and the 90th percentiles. The dots represent the 5 th and the 95 th percentiles

$14.8 \%$ in the summer-autumn, whereas their relative contribution dropped to $43.0 \pm 21.9 \%$ in the winter. This drop correlated with an increase of PICOEuk contribution: $32.4 \pm$ $16.9 \%$ in the winter vs. $11.4 \pm 8.6 \%$ in the summer-autumn. At both sites, the relative contribution of CRYPTO was weak $(<2.5 \%)$.

Variability was observed between 2014 and 2015 at both sites. From the spring to the autumn, a strong growth of SYN1 population occurred in 2015 ( $48.9 \pm 21.7 \%$ in 2014 vs. $67.4 \pm$ $17.5 \%$ in 2015 , values for pooled sites) to the detriment of PICOEuk $(24.5 \pm 12.2 \%$ in 2014 vs. $16.7 \pm 11.4 \%$ in 2015), PROCHL ( $9.1 \pm 5.7 \%$ in 2014 vs. $4.7 \pm 4.5 \%$ in 2015$)$ and NANOEuk (14.9 $\pm 7.3 \%$ in 2014 vs. $9.4 \pm 6.8 \%$ in 2015$)$. Conversely, in the winter, the relative contribution of SYN1 was not as large, either in $\mathrm{LiB}(28.3 \%$ in 2014 vs. $16.6 \%$ in 2015 ) or in $\mathrm{LaB}$ (45.7\% in 2014 vs. $40.3 \%$ in 2015).

Redundancy analyses (RDA) were then performed for both sites to identify the environmental factors driving the abundance of the various pico- and nanophytoplankton groups (Fig. 8). The axis significance test (ANOVA-like) identified axis 1 as the only significant one $(50.5 \%$ of the total variance in $\mathrm{LiB}$ and $57.0 \%$ in $\mathrm{LaB}$ ). Among the five environmental parameters considered in these analyses (i.e. temperature, salinity, dissolved oxygen, $\mathrm{N}-\mathrm{NO}_{\mathrm{x}}{ }^{-}$and $\mathrm{P}-\mathrm{PO}_{4}{ }^{3-}$ concentrations), three displayed a significant influence to explain the model tested for LiB, and these were represented in Fig. 8a. A negative correlation between temperature and $\mathrm{N}^{-N}{ }_{\mathrm{x}}^{-}$concentration was observed. While SYN1 and CRYPTO were correlated positively with temperature and salinity, PROCHL and PICOEuk were significantly linked with N$\mathrm{NO}_{\mathrm{x}}{ }^{-}$concentration and inversely correlated with temperature. For LaB, only temperature and salinity had a significant influence (Fig. 8b). A seasonal signal was observed, with a negative correlation between temperature and most pico- or nanophytoplankton populations (i.e. PROCHL, CRYPTO and PICOEuk). Only SYN1 were correlated positively with temperature, but to a lesser extent.

Temperature and salinity were identified as being significantly influential for both sites. These two fundamental factors serve as proxies for monitoring environmental changes as they 

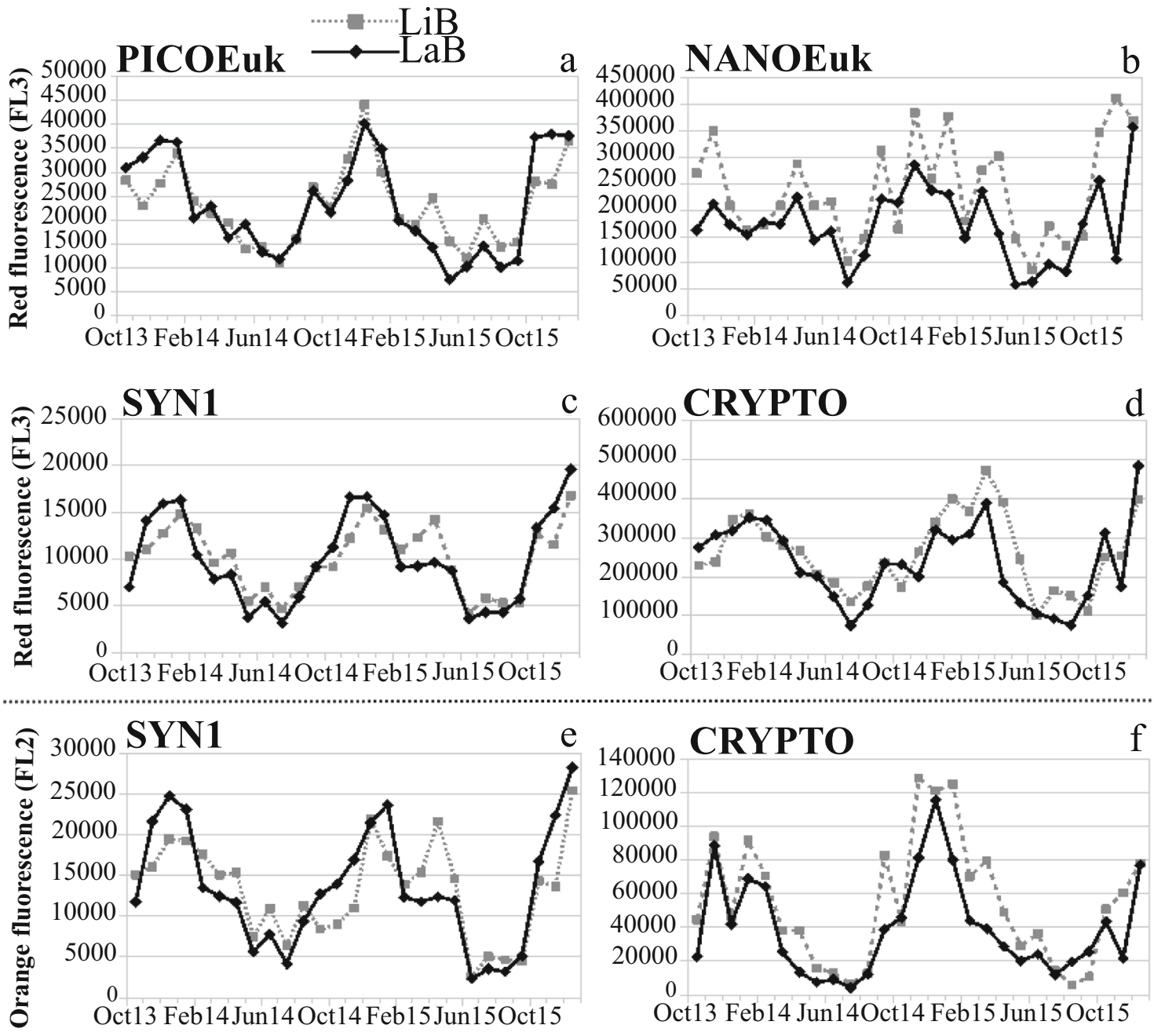

Fig. 6 Temporal variations of red fluorescence intensity (FL3) for PICOEuk (a), NANOEuk (b), SYN1 (c) and CRYPTO (d), as well as of orange fluorescence intensity (FL2) for the last two (e and $\mathbf{f}$,

respectively), in $\mathrm{LiB}$ and $\mathrm{LaB}$. Data were averages of that obtained at depths of 3 and $10 \mathrm{~m}$

were likely correlated with other factors which were not measured in this study. They were thus selected for two-

dimensional surface plots showing their direct and/or indirect effects on the abundance of each pico- or nanophytoplankton

Table 1 Results of PERMANOVA analysis carried out on Bray-Curtis distances for the structure of the pico- and nanophytoplankton communities in relation to the site, the season and the year. Df, degrees of freedom; F.Model, F value by permutation

\begin{tabular}{lrllllll}
\hline & Df & $\begin{array}{l}\text { Sum of } \\
\text { squares }\end{array}$ & $\begin{array}{l}\text { Mean sum } \\
\text { of square }\end{array}$ & F.Model & $R^{2}$ & $p$ value \\
\hline Site & 1 & 1.621 & 1.621 & 32.965 & 0.179 & $<0.001$ & $* * *$ \\
Season & 3 & 1.376 & 0.459 & 9.329 & 0.152 & $<0.001$ & $* * *$ \\
Year & 1 & 0.299 & 0.299 & 6.071 & 0.033 & 0.003 & $* *$ \\
Site:Season & 3 & 0.351 & 0.117 & 2.376 & 0.039 & 0.018 & $*$ \\
Season:Year & 3 & 0.738 & 0.246 & 5.002 & 0.081 & $<0.001$ & $* * *$ \\
Site:Year & 1 & 0.071 & 0.071 & 1.449 & 0.008 & 0.228 & \\
Residuals & 94 & 4.622 & 0.049 & 0.509 & & & \\
Total & 106 & 9.078 & & & & & \\
\hline
\end{tabular}

${ }^{*} 0.01<p<0.05$

** $0.001<p<0.01$

${ }^{* * *} p<0.001$ 


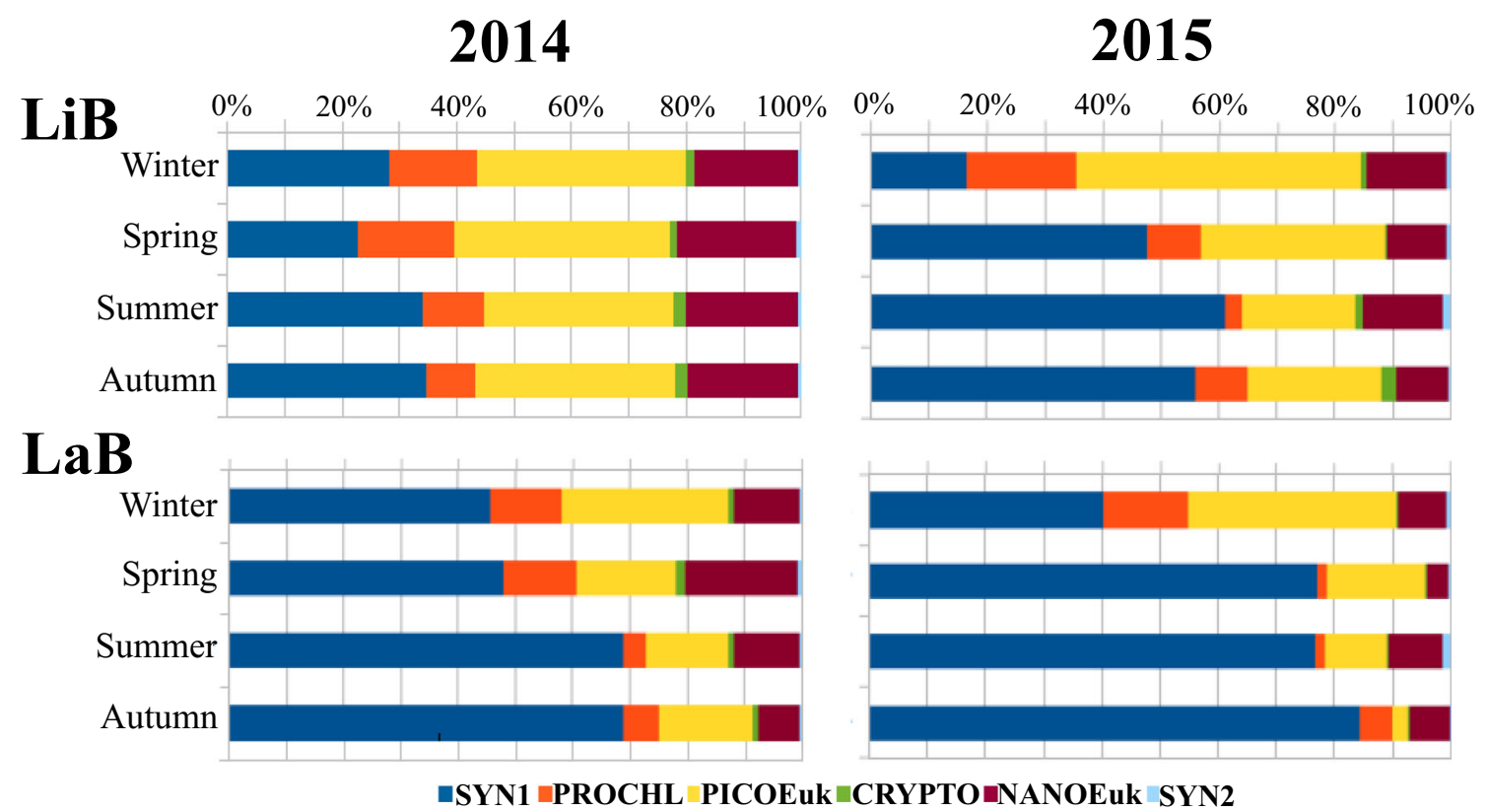

Fig. 7 Seasonal variations of relative contribution in abundance (\%) of main pico- and nanophytoplankton groups for LiB and LaB in 2014 and 2015

population (Fig. 9a-f). SYN1 had two ranges of optimal values $\left(\sim 15.5^{\circ} \mathrm{C}\right.$ and $\left.>21^{\circ} \mathrm{C}\right)$, whereas a reverse pattern $\left(<15^{\circ} \mathrm{C}\right.$ and 16 to $20^{\circ} \mathrm{C}$ ) was observed for PROCHL and PICOEuk. SYN2 and CRYPTO reached their highest abundance during warm periods $\left(>19{ }^{\circ} \mathrm{C}\right)$. Likewise, NANOEuk were particularly observed at $18.5,20$ and $>22^{\circ} \mathrm{C}$. SYN1, PROCHL, PICOEuk and NANOEuk were present in high abundance whatever the salinity, while SYN2 and CRYPTO seemed to prefer a salinity of about 38 . The pooling of previous two-dimensional surface plots

\section{LiB}

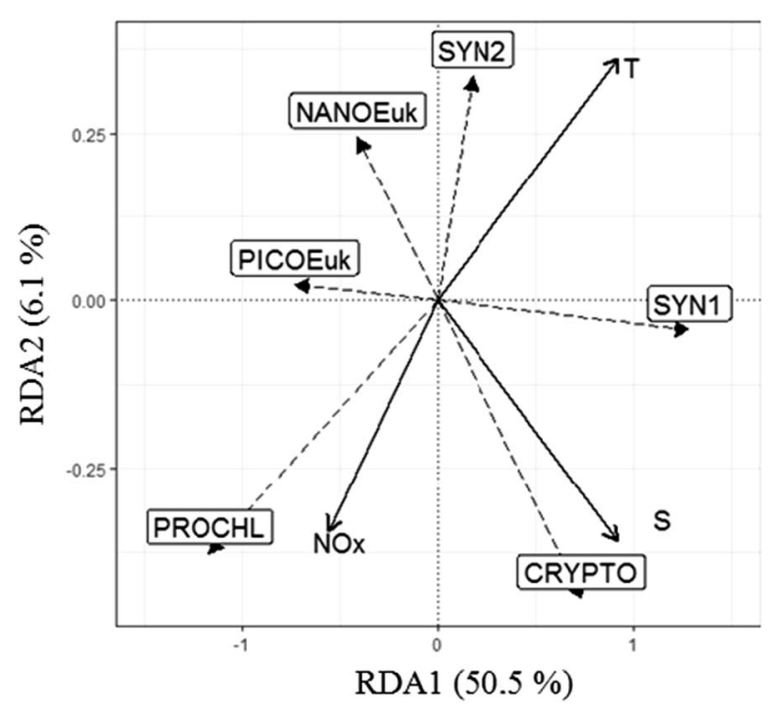

Fig. 8 Triplots of redundancy analyses in scaling 2 for $\mathrm{LiB}$ (a) and $\mathrm{LaB}$ (b). Explanatory variables (environmental parameters) were represented by solid vectors and response variables (pico- and nanophytoplankton highlighted a clear succession on the structure of the pico- and nanophytoplankton assemblage, depending on temperature (Fig. 9g). Below $14{ }^{\circ} \mathrm{C}$, PICOEuk and PROCHL were particularly abundant. An inverse trend was observed at $15^{\circ} \mathrm{C}$ with a community dominated by SYN1. Between 16 and $19{ }^{\circ} \mathrm{C}$, PICOEuk and PROCHL reappeared, this time accompanied by some NANOEuk. Above $20{ }^{\circ} \mathrm{C}$, the pico- and nanophytoplankton community was mainly composed of SYN1, joined SYN2, NANOEuk and CRYPTO above $21{ }^{\circ} \mathrm{C}$.

\section{LaB}

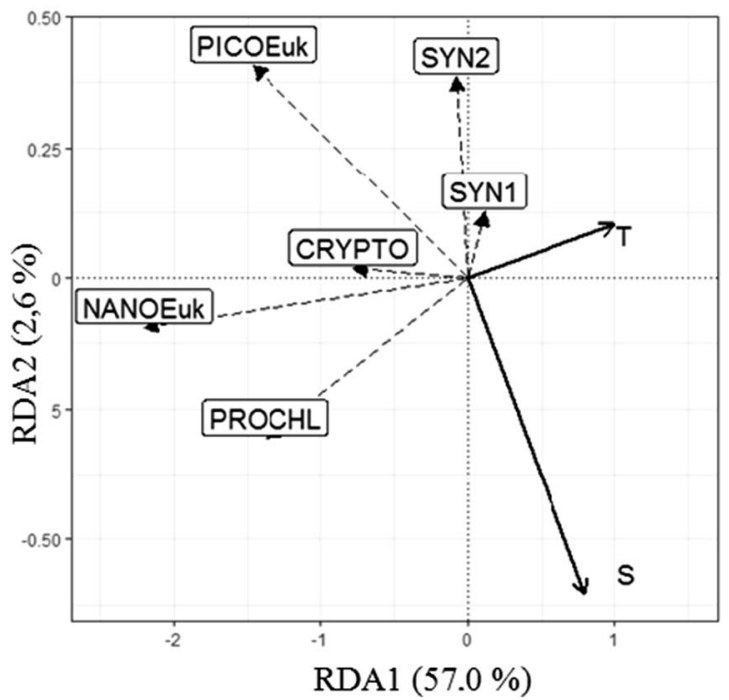

groups) by dotted vectors. They were only represented when significant. Abbreviations for the environmental parameters: T, temperature; S, salinity; $\mathrm{NOx}, \mathrm{N}^{-\mathrm{NO}_{\mathrm{x}}}{ }^{-}$concentration 

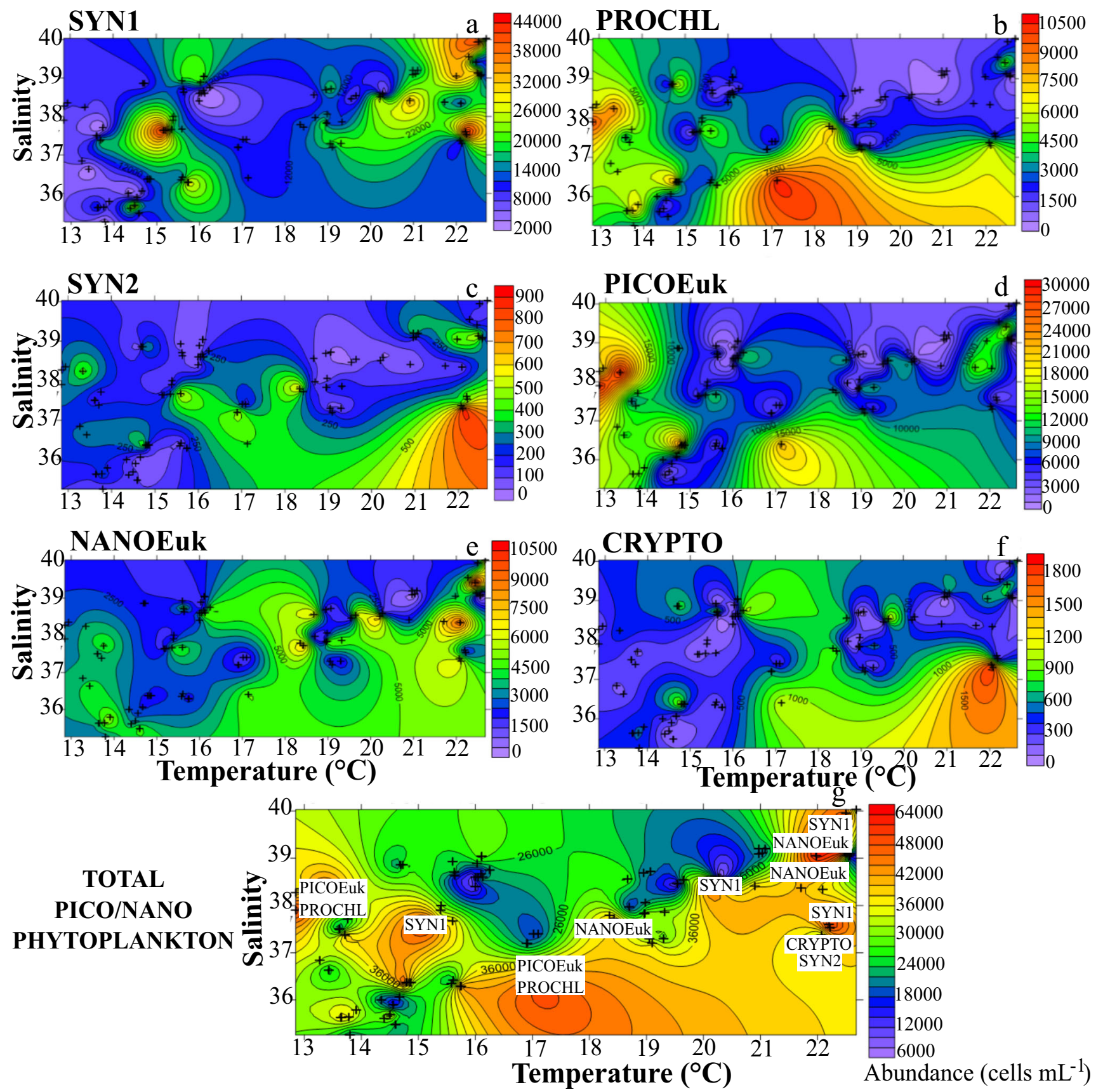

Fig. 9 Distribution of abundance of each pico- or nanophytoplankton cluster (SYN1-a, PROCHL-b, SYN2-ce, PICOEuk-d, NANOEuk - d and CRYPTO-f) depending on temperature $\left({ }^{\circ} \mathrm{C}\right)$ and

\section{Discussion}

In the context of global change and impact of human activities on coastal areas, the environmental monitoring of marine ecosystems is crucial for understanding and predicting their evolution. Due to the vicinity of Toulon city, two connected but contrasting coastal ecosystems (Little bay and Large bay) are characterized by different human pressures. The semi-enclosed salinity. Summary of the contributions of each group to the distribution of total pico- and nanophytoplankton abundance depending on temperature and salinity $(\mathbf{g})$

Little bay is impacted by a severe contamination, coming from commercial and military harbors, various industries and shipyards, in sediment and water levels (Tessier et al. 2011; Pougnet et al. 2014; Coclet et al. 2017). Conversely, the Large bay is open to offshore seawaters and is influenced by the North current. It has a better water quality, with less contaminants and significantly higher oxygen concentrations. If two key compartments of these ecosystems (i.e. zooplankton 
and large phytoplankton) have already been investigated along long-term time series (Jamet et al. 2001; Rossi and Jamet 2009; Serranito et al. 2016), there has been no study devoted to the pico- and nanophytoplankton communities. Considered as good bio-indicators of water quality (Grégori et al. 2001; Caroppo et al. 2006), pico- and nanophytoplankton exhibited an important dichotomy in terms of abundance and composition depending on the sampling sites. Higher pico- and nanophytoplankton abundance was observed in the Little bay than in the Large bay, following the trends observed for other higher planktonic compartments (Jamet et al. 2001; Rossi and Jamet 2009; Serranito et al. 2016). Concerning the composition, microphytoplankton and zooplankton communities were generally less diversified in the Little bay than in the Large bay (Jamet et al. 2001; Rossi and Jamet 2008). Pico- and nanophytoplankton exhibited in the Little bay a community represented by several co-dominant groups (i.e. Synechococcus 1-like, picoeukaryotes, nanoeukaryotes and Prochlorococcus-like), while in the Large bay, the community was largely dominated by Synechococcus 1-like.

Previous studies described the Little bay as being more eutrophic than the Large bay because of significantly higher nutrient and chlorophyll $a$ concentrations (Rossi 2008; Rossi

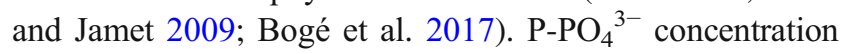
measured in this study confirmed this trend, even if values were close to the detection limit. As the Little bay is a shallow basin (mean depth of $15 \mathrm{~m}$ ) with a high water residence time (3-6 days), phosphates can be released from sediments during resuspension phenomena induced by an intense maritime traffic (i.e. commercial and military harbors) and by occasional strong wind events. In the Large bay, waters are regularly mixed with offshore seawaters and exhibited lower $\mathrm{P}_{-} \mathrm{PO}_{4}{ }^{3-}$ concentrations. Furthermore, the predominance of Synechococcus 1-like in this site, which can contribute up to $35 \%$ of the total Pi uptake, could participate in these low P$\mathrm{PO}_{4}{ }^{3-}$ values (Talarmin et al. 2015). The opposite situation was observed for nitrite/nitrate with higher concentrations in the Large bay than in the Little bay. In the Large bay, nitrate intakes come mainly from the Eygoutier River with a baseflow ranging from 1 to $10 \mathrm{mg} \mathrm{L}^{-1}$ depending on season

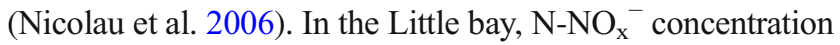
was identified as an explicative variable by redundancy analysis. This site knows regular phytoplankton blooms whose growth depends on a sufficient supply of nutrients (Rossi 2008). Pico- and nanoeukaryotes constituted the most successful groups in coastal eutrophic waters and were particularly abundant in this site (Pan et al. 2007; Jyothibabu et al. 2013). With respect to cyanobacteria, $\mathrm{N}_{-} \mathrm{NO}_{\mathrm{x}}^{-}$concentration had a positive correlation with Prochlorococcus-like cells. Šantić et al. (2011) highlighted that the abundance of Prochlorococcus can be influenced by nutrient availability, but as a consequence of the movement of water mass. Other environmental conditions, such as temperature, salinity, water turbidity and irradiance, could thus explain these spatiotemporal variations, leading to the presence of high abundances during periods of heavy rains and floods.

Furthermore, numerous studies evidenced the intense contamination of the Little bay by organometallic (e.g. TBT, DBT and MBT), organic (e.g. HAP and PCB) and metallic (e.g. $\mathrm{Hg}, \mathrm{Cu}, \mathrm{Pb}, \mathrm{Zn}$ and $\mathrm{Cd}$ ) pollutants (Tessier et al. 2011; Tessier 2012; Pougnet et al. 2014). In surface water, Coclet et al. (2017) highlighted clear decreasing gradients of dissolved copper and lead from the Little bay ( 7.9 to $121.0 \mathrm{nM} \mathrm{Cu}$ and 0.4 to $12.7 \mathrm{nM} \mathrm{Pb}$ ) to the Large bay (2.4 to $16.0 \mathrm{nM} \mathrm{Cu}$ and 0.08 to $0.73 \mathrm{nM} \mathrm{Pb}$ ). Phytoplankton resistance to metallic contaminants was strongly related to cell size, highlighting that picocyanobacteria were more sensitive than other functional groups (Echeveste et al. 2012). In Toulon bays, pico- and nanophytoplankton community exhibited either a codominance of picoeukaryotes, nanoeukaryotes, Synechococcus-like and Prochlorococcus-like cells in the most contaminated site (LiB), or a Synechococcus 1-like dominated community in the site near the open sea $(\mathrm{LaB})$. Synechococcus can be actually impacted by copper with a major inhibition of its growth rate (Debelius et al. 2009, 2011). Coclet et al. (2017) exposed pico- and nanophytoplankton collected in the less impacted area of Large bay to a trace metal cocktail $(\mathrm{Cu}, \mathrm{Pb}$ and $\mathrm{Zn})$. These laboratory experiments revealed a shift from a Synechococcus-like dominated community towards a community such as that observed in Little bay, confirming the sensibility of this strain to metallic contaminants. These results were compared to the pico- and nanophytoplankton composition observed at the neighboring SOLEMIOMarseille station $\left(43^{\circ} 14^{\prime} 30^{\prime \prime} \mathrm{N} / 05^{\circ} 17^{\prime} 30^{\prime \prime} \mathrm{E}\right)$, used as external reference. This station belongs to the SOMLIT (Service d'Observation en Milieu LITtoral, INSU-CNRS) French National Network. Its aims are to coordinate the observation activities (e.g. in situ sampling, measurements and analyses) in marine laboratories along the French coastlines and to assure the distribution of acquired data for the different parameters monitored by SOMLIT (T, S, $\mathrm{O}_{2}, \mathrm{NH}_{4}, \mathrm{NO}_{3}, \mathrm{NO}_{2}, \mathrm{PO}_{4}, \mathrm{SiOH}_{4}, \mathrm{COP}$, NOP, MES, CHL $a, \delta^{15} \mathrm{~N}, \delta^{13} \mathrm{C}$, pico- and nanoplankton) via its website (http://somlit.epoc.u-bordeaux1.fr/fr/). Located in the Northwestern Mediterranean basin (Marseille, France), the SOLEMIO station constitutes an external Mediterranean coastal reference site located in the vicinity of Toulon. Over the whole year, the predominance of Synechococcus 1-like was intensified in the Marseille bay (mean value of $\sim 23,737$ cells $\mathrm{mL}^{-1}$ ) in comparison to the Large bay $\left(\sim 18,106\right.$ cells $\left.\mathrm{mL}^{-1}\right)$, whereas the other groups were significantly less abundant than in the Little bay $\left(\sim 3612\right.$ and 10,867 cells $\mathrm{mL}^{-1}$ for picoeukaryotes, $\sim 1362$ and 4501 cells $\mathrm{mL}^{-1}$ for 
nanoeukaryotes, $\sim 97$ and 602 cells $\mathrm{mL}^{-1}$ for Cryptophyceae, respectively, for the Marseille bay and the Little bay) (data provided by the "Service d'Observation en Milieu Littoral, INSU-CNRS, Marseille"). These observations outline a major impact from the local context on the pico- and nanophytoplankton structure and confirm the preponderance of Synechoccocus-like cells in the farther offshore environments. These cells are likely close to more open sea strains since genomic sequencing analyses have revealed the existence of coastal Synechococcus strains that are tolerant to metals, especially copper and iron (Palenik et al. 2006).

As highlighted by the PERMANOVA analysis, the differences in terms of composition between the two sites are explained by the two sites themselves. Thus, the different human pressures discriminating the sites mostly perturb the seasonal dynamics of Synechococcus 1-like cells and Cryptophyceae and confirm their greater sensitivity (Debelius et al. 2009, 2011; Kirkham et al. 2011). However, strong positive correlations were evidenced between the connected Little and Large bays for the other groups (i.e. Prochlorococcus-like, picoeukaryotes, nanoeukaryotes and Synechococcus 2-like). Temperature and salinity, which were comparable in the two sites, were identified by our RDA analyses as environmental factors influencing the pico- and nanophytoplankton distribution. In the Toulon bays, pico- and nanophytoplankton community had two structures either with Synechococcus 1-like cells correlated to high temperature and high salinity or with picoeukaryotes/Prochlorococcus-like cells correlated to low temperature and low salinity. Synechococcus-like populations had two optimal temperatures corresponding to conditions observed in early spring and late autumn $\left(\sim 15^{\circ} \mathrm{C}\right)$ for Synechococcus 1-like, and in the summer $\left(>21^{\circ} \mathrm{C}\right)$ for Synechococcus 1-like and Synechococcus 2-like. The genetic diversity of marine Synechococcus is complex with several clades widely distributed in the Mediterranean Sea (MellaFlores et al. 2011). Amorim et al. (2016) suggested that, in the Northern Alboran Sea (Spain, W Mediterranean), there were different ecotypes of Synechococcus which were adapted either to summer conditions or to winter ones. However, Synechococcus-like populations are known to further develop in the summer demonstrating a growth rate which was maximized by warm and stratified waters, as well as a limitation of nutrients (Agawin et al. 1998; Moisan et al. 2010). During this time, Synechococcus-like cells would be too abundant for the grazing capacity of their predators, and so represent a major source of organic carbon and nutrients for coastal Mediterranean food webs (Agawin et al. 1998). Conversely, picoeukaryotes and Prochlorococcus-like cells were particularly abundant in the winter (i.e. $<15{ }^{\circ} \mathrm{C}$ ). Marine picoeukaryotes could have a higher photosynthetic activity inducing a better use of light and allowing them to be more competitive at low temperature and low light intensity
(Somogyi et al. 2009). As for the Prochlorococcus-like cluster, their proliferation at temperature $<15^{\circ} \mathrm{C}$ is unusual. At a global scale, their higher abundances were observed in warm waters as demonstrated by Flombaum et al. (2013). Nevertheless, several studies reported abundances of $10^{3}$ $10^{4}$ cells $\mathrm{mL}^{-1}$ in the winter (temperature $<15{ }^{\circ} \mathrm{C}$ ) in the Mediterranean Sea (Vaulot and Partensky 1990; Babić et al. 2017; Salhi et al. 2017). Prochlorococcus has even been detected within temperatures ranging from 6.33 to $26.93{ }^{\circ} \mathrm{C}$ in the Adriatic Sea (Šantić et al. 2011). Our datasets also showed that the largest cells (i.e. nanoeukaryotes and Cryptophyceae) were more abundant in warmer waters $\left(>19^{\circ} \mathrm{C}\right)$.

Moreover, seasonal variations were observed on red and orange fluorescence intensities of some pico- and nanophytoplankton groups, namely: Synechococcus 1like, picoeukaryotes, nanoeukaryotes and Cryptophyceae. Red and orange fluorescence intensities are related to the amounts of two photosynthetic pigments: chlorophyll $a$ and phycoerythrin, respectively. Maximum values were first observed in the autumn-winter, when irradiance is low, as phytoplanktonic cells need to produce more antennas for a better efficiency of the photon collection that is mandatory for photosynthesis. Then, fluorescence intensities reached minimum values in late spring-early summer when cells are developing and more irradiance is available, thus less pigments are needed. These seasonal changes of fluorescence intensities appeared to be inversely related to those of cell abundances, reflecting probable blooms of small cells in late spring-early summer (DuRand et al. 2001). This decrease also illustrates a photoacclimation strategy to prevent any damage of the photosynthetic apparatus, particularly of the Photosystem II complex (Mella-Flores et al. 2012; Murphy et al. 2017). It is worth noting that nanoeukaryotes were the only group with a significant difference of fluorescence intensities between the two sites. The higher values observed in the Little bay can be explained by either a higher turbidity limiting the amount of light perceived by cells which synthetized in response more pigments, or by the presence of different species depending on the environmental conditions of each site.

Combining all these observations, we have demonstrated the specific situation of the Toulon bays. On the one hand, pico- and nanophytoplankton composition and dynamics were driven by temperature. On the other hand, the various contaminations reported in the literature and the nutrient conditions influenced by human pressures might deeply modulate the predominance of one or more clusters. Indeed, the redundancy analyses evidenced a negative correlation between Synechococcus 1-like and the other picoand nanophytoplankton groups in the Little bay. When environmental conditions were not suitable for the growth of a major Synechococcus 1-like population, 
Prochlorococcus-like cells reach their highest abundance. The opposition of these two cyanobacteria clusters reflects differences in life strategy, as well as ecological niches (Partensky et al. 1999; Mella-Flores et al. 2012). Likewise, pico- and nanoeukaryotes proliferate in the Little bay where Synechococcus 1-like was less abundant as they develop successfully in coastal eutrophic waters (Pan et al. 2007; Jyothibabu et al. 2013).

\section{Conclusion}

The monitoring of Toulon bay contributes to an effort to survey marine environments through two French national networks (i.e. RESOMAR-REseaux des Stations et Observatoires MARins, SOMLIT-Service d'Observation en Milieu LITtoral-INSU CNRS) and a European one (i.e. MSFD-Marine Strategy Framework DirectiveEuropean Commission). This effort takes place within a harmonisation process of protocols for sampling, measurement and analysis to obtain exploitable and intercomparable datasets. Multiplication of such lowfrequency monitoring are essential for understanding the natural dynamics of plankton communities and for assessing the evolution of marine ecosystems in the context of the global change and human pressures. Thus, in Toulon bay, we emphasized the typical presence of Synechococcus 1-like in summer and the unusual one of Prochlorococcus-like in winter. At spatial scale, the low abundance of Synechococcus 1-like in the site the most impacted by human activities is probably related to chronic exposures of pico- and nanophytoplankton to contaminants, such as trace metals. This Synechococcus strain could be used as a bioindicator of sudden environmental perturbations in this area, as demonstrated in laboratory experiments by Coclet et al. (2017). To this end, such monitoring could be completed by in situ automated flow cytometers capable of performing automated high frequency sampling and analysis (several times per hour) to track any significant sudden change in their abundance and/or their optical properties (Dugenne et al. 2014; Thyssen et al. 2014). The seasonal patterns pointed out by our study contribute to a better understanding of the pico- and nanophytoplankton role in the environments under multiple human stressors. Their monthly monitoring should then be continued in Toulon bay to supply the existing long-term dataset to the other plankton compartments (i.e. microphytoplankton and zooplankton), allowing to refine knowledge and predictions of coastal ecosystem functioning in the context of the global warming in the Mediterranean Sea.
Acknowledgements This research was financed by in-house funding from the EBMA (Marine Ecology and Biology) research team (PROTEE laboratory EA 3819, University of Toulon, France). We are grateful to the Regional Flow Cytometry Platform for Microbiology (PRECYM) of the Mediterranean Institute of Oceanography (MIO UM 110, Aix-Marseille University, France) for their support concerning the arrangement of our flow cytometry protocols and sample preparation. The authors thank Jingwei YANG $(\mathrm{PhD})$ for help in implementing flow cytometry in the laboratory, as well as the two anonymous reviewers that provided helpful comments on the earlier draft of this manuscript.

Funding This research was financed by in-house funding from the EBMA (Marine Ecology and Biology) research team (PROTEE laboratory EA 3819, University of Toulon, France).

\section{References}

Agawin, Nona S.R., Carlos M. Duarte, and Susana Agustí. 1998. Growth and abundance of Synechococcus sp. in a Mediterranean Bay: Seasonality and relationship with temperature. Marine Ecology Progress Series 170: 45-53.

Agawin, Nona S.R., Carlos M. Duarte, and Susana Agustí. 2000. Nutrient and temperature control of the contribution of picoplankton to phytoplankton biomass and production. Limnology and Oceanography 45 (3): 591-600.

Amorim, Ana L., Pablo León, Jesús M. Mercado, Dolores Cortés, Francisco Gómez, Sebastien Putzeys, Soluna Salles, and Lidia Yebra. 2016. Controls of picophytoplankton abundance and composition in a highly dynamic marine system, the Northern Alboran Sea (Western Mediterranean). Journal of Sea Research 112: 13-22.

Anderson, Marti J. 2001. A new method for non-parametric multivariate analysis of variance. Austral Ecology 26: 32-46.

Babić, Ivana, Ines Petrić, Sunčica Bosak, Hrvoje Mihanović, Iris Dupčić Radić, and Zrinka Ljubešić. 2017. Distribution and diversity of marine picocyanobacteria community: Targeting of Prochlorococcus ecotypes in winter conditions (southern Adriatic Sea). Marine Genomics 36: 3-11.

Bec, Béatrice, Yves Collos, Philippe Souchu, André Vaquer, Jacques Lautier, Annie Fiandrino, Laurent Benau, Valérie Orsoni, and Thierry Laugier. 2011. Distribution of picophytoplankton and nanophytoplankton along an anthropogenic eutrophication gradient in French Mediterranean coastal lagoons. Aquatic Microbial Ecology 63 (1): 29-45.

Belin, Catherine, and Bernard Raffin. 1998. Toxic and harmful phytoplankton species on the French coast from 1984 to 1995, results of the French phytoplankton and phycotoxins monitoring network (REPHY). Rapport IFREMER. http://envlit.ifremer.fr/content/ download/27379/222288/file/Rephy_84_95.pdf. Accessed August 2017. 
Bell, Thomas, and Jacob Kalff. 2001. The contribution of picophytoplankton in marine and freshwater systems of different trophic status and depth. Limnology and Oceanography 46 (5): $1243-1248$.

Bogé, Gérard, Magali Lespilette, Dominique Jamet, and Jean-Louis Jamet. 2017. Role of DOP on the alkaline phosphatase activity of size fractionated plankton in coastal waters in the NW Mediterranean Sea (Toulon Bay, France). Marine Pollution Bulletin 117 (1-2): 264-273.

Bosak, Sunčica, Tina Šilović, Zrinka Ljubešić, Grozdan Kušpilić, Branka Pestorić, Sladana Krivolapić, and Damir Viličić. 2012. Phytoplankton size structure and species composition as an indicator of trophic status in transitional ecosystems: The case study of a Mediterranean fjord-like karstic bay. Oceanologica 54 (2): 255-286.

Caroppo, Carmela, Loredana Stabili, Michele Aresta, Cinzia Corinaldesi, and Roberto Danovaro. 2006. Impact of heavy metals and PCBs on marine picoplankton. Environmental Toxicology 21 (6): 541-551.

Clementson, Lesley A., and Sally E. Wayte. 1992. The effect of frozen storage of open-ocean seawater samples on the concentration of dissolved phosphate and nitrate. Water Research 26 (9): 1171-1176.

Coclet, Clément, Cédric Garnier, Floriane Delpy, Dominique Jamet, Gaël Durrieu, Christophe Le Poupon, Marie Mayer, and Benjamin Misson. 2017. Trace metal contamination as a toxic and structuring factor impacting ultraphytoplankton communities in a multicontaminated Mediterranean coastal area. Progress in Oceanography. https://doi.org/10.1016/j.pocean.2017.06.006.

Dang, Duc Huy, Véronique Lenoble, Gaël Durrieu, Jean-Ulrich Mullot, Stéphane Mounier, and Cédric Garnier. 2014. Sedimentary dynamics of coastal organic matter: An assessment of the porewater size/ reactivity model by spectroscopic techniques. Estuarine, Coastal and Shelf Science 151: 100-111.

Debelius, Bibiana, Jesús M. Forja, Ángel DelValls, and Luis M. Lubián. 2009. Toxicity of copper in natural marine picoplankton populations. Ecotoxicology 18 (8): 1095-1103.

Debelius, Bibiana, Jesús M. Forja, and Luis M. Lubián. 2011. Toxicity of copper, nickel and zinc to Synechococcus populations from the Strait of Gibraltar. Journal of Marine Systems 88 (1): 113-119.

Denis, Michel, Valérie Martin, and Valérie Andersen. 2000. Short-term variations of the vertical distribution of cyanobacteria in the open Mediterranean Sea. Scientia Marina 64 (2): 157-163.

Dore, John E., Terrence Houlihan, Dale V. Hebel, Georgia Tien, Luis Tupas, and David M. Karl. 1996. Freezing as a method of sample preservation for the analysis of dissolved inorganic nutrients in seawater. Marine Chemistry 53 (3-4): 173-185.

Dubelaar, George B.J., and Richard R. Jonker. 2000. Flow cytometry as a tool for the study of phytoplankton. Scientia Marina 64 (2): 135-156.

Duffa, Céline, François Dufois, and Sylvain Coudray. 2011. An operational model to simulate post-accidental radionuclide transfers in Toulon marine area: Preliminary development. Ocean Dynamics 61 (11): 1811-1821.

Dufresne, Christiane, Céline Duffa, and Vincent Rey. 2014. Wind-forced circulation model and water exchanges through the channel in the Bay of Toulon. Ocean Dynamics 64 (2): 209-224.

Dugenne, Mathilde, Melilotus Thyssen, David Nerini, Claude Mante, Jean-Christophe Poggiale, Nicole Garcia, Fabrice Garcia, and Gérald J. Grégori. 2014. Consequence of a sudden wind event on the dynamics of a coastal phytoplankton community: An insight into specific population growth rates using a single cell high frequency approach. Frontiers in Microbiology 5: 485. https://doi.org/10.3389/ fmicb.2014.00485.

DuRand, Michele, Robert J. Olson, and Sallie W. Chisholm. 2001. Phytoplankton population dynamics at the Bermuda AtlanticTime-series station in the Sargasso Sea. Deep-Sea Research II 48 (8-9): 1983-2003.

Echeveste, Pedro, Susana Agustí, and Antonio Tovar-Sánchez. 2012. Toxic thresholds of cadmium and lead to oceanic phytoplankton:
Cell size and ocean bassin-dependant effect. Environmental Toxicology and Chemistry 31 (8): 1887-1894.

Flombaum, Pedro, José L. Gallegos, Rodolfo A. Gordillo, José Rincón, Lina L. Zabala, Nianzhi Jiao, David M. Karl, William K.W. Li, Michael W. Lomas, Daniele Veneziano, Carolina S. Vera, Jasper A. Vrugt, and Adam C. Martiny. 2013. Present and future global distributions of the marine cyanobacteria Prochlorococcus and Synechococcus. PNAS 110 (24): 9824-9829.

Fogg, Gordon E. 1995. Some comments on picoplankton and its importance in the pelagic ecosystem. Aquatic Microbial Ecology 9: 33-39.

Goffart, Anne, Jean-Henri Hecq, and Louis Legendre. 2015. Drivers of the winter-spring phytoplankton bloom in a pristine NW Mediterranean site, the bay of Calvi (Corsica): A long-term study (1979-2011). Progress in Oceanography 137 (A): 121-139.

Grégori, Gérald, Alfredo Colosimo, and Michel Denis. 2001. Phytoplankton group dynamics in the Bay of Marseilles during a 2-year survey based on analytical flow cytometry. Cytometry 44 (3): $247-256$

Jamet, Jean-Louis, Gérard Bogé, Simone Richard, Claude Geneys, and Dominique Jamet. 2001. The zooplankton community in bays of Toulon area (northwest Mediterranean Sea, France). Hydrobiologia 457 (1/3): 155-165.

Joanny, Michel, Catherine Belin, Didier Claisse, Laurence Miossec, JeanPaul Berthome, Anne Grouhel, and Bernard Raffin. 1993. Qualité du milieu marin littoral. Rapport IFREMER. http://archimer.ifremer. fr/doc/00334/44475/44153.pdf. Accessed August 2017.

Jouan, Matthieu, Pierre Garreau, and Olivier Raillard. 2001. Modélisation de la Rade de Toulon: test méthodologique. Rapport IFREMER.

Jyothibabu, Retnamma, Arya P. Mohan, Jagadeesan Loganthan, A. Anjusha, K.R. Muraleedharan, Raj Lallu, Krishna Kiran, and Nanappan Ullas. 2013. Ecology and trophic preference of picoplankton and nanoplankton in the Gulf of Mannar and the Palk Bay, southeast coast of India. Journal of Marine Systems 111-112: 29-44.

Karydis, Michael, and Dimitra Kitsiou. 2012. Eutrophication and environmental policy in the Mediterranean Sea: A review. Environmental Monitoring and Assessment 184 (8): 4931-4984.

Kirkham, Amy R., Ludwig E. Jardillier, Ana Tiganescu, John Pearman, Mikhail V. Zubkov, and David J. Scanlan. 2011. Basin-scale distribution patterns of photosynthetic picoeukaryotes along an Atlantic Meridional Transect. Environmental Microbiology 13 (4): 975-990.

Lomas, Michael W., and S. Bradley Moran. 2011. Evidence for aggregation and export of cyanobacteria and nano-eukaryotes from the Sargasso Sea euphotic zone. Biogeosciences 8 (1): 203-216.

Mann, Henry B., and Donald R. Whitney. 1947. On a test of whether one of two random variables is stochastically larger than the other. The Annals of Mathematical Statistics 18 (1): 50-60.

Marie, Dominique, Frédéric Partensky, Stephan Jacquet, and Daniel Vaulot. 1997. Enumeration and cell cycle analysis of natural populations of marine picoplankton by flow cytometry using the nucleic acid stain SYBR Green I. Applied and Environmental Microbiology 63 (1): 186-193.

Marie, Dominique, Frédéric Partensky, Daniel Vaulot, and Corina Brussaard. 2001. Enumeration of phytoplankton, bacteria, and viruses in marine samples. In Current protocols in cytometry, eds. J. Paul Robinson, Zbyszek Darzynkiewicz, Philipp N. Dean, Alberto Orfao, Peter S. Rabinovitch, Carleton C. Stewart, Hans J. Tanke, and Leon L. Wheeless, Supplement 10: 11.11.1-11.11.15. New York: Wiley.

Marie, Dominique, Fabienne Rigaut-Jalabert, and Daniel Vaulot. 2014. An improved protocol for flow cytometry analysis of phytoplankton cultures and natural samples. Cytometry. Part A 85 (11): 962-968.

Mella-Flores, Daniella, Sophie Mazard, Florian Humily, Frédéric Partensky, Frédéric Mahé, Laetitia Bariat, Claude Courties, Dominique Marie, Joséphine Ras, Romain Mauriac, Christian Jeanthon, El Mahdi Bendif, Martin Ostrowski, 
David J. Scanlan, and Laurence Garczarek. 2011. Is the distribution of Prochlorococcus and Synechococcus ecotypes in the Mediterranean Sea affected by global warming? Biogeosciences 8 (9): 2785-2804.

Mella-Flores, Daniella, Christophe Six, Morgane Ratin, Frédéric Partensky, Christophe Boutte, Gildas Le Corguillé, Dominique Marie, Nicolas Blot, Priscillia Gourvil, Christian Kolowrat, and Laurence Garczarek. 2012. Prochlorococcus and Synechococcus have evolved different adaptive mechanisms to cope with light and UV stress. Frontiers in Microbiology 3: 285. https://doi.org/10. 3389/fmicb.2012.00285.

Moisan, Tiffany A., Kristen L. Blattner, and Carla P. Makinen. 2010. Influences of temperature and nutrients on Synechococcus abundance and biomass in the southern Mid-Atlantic Bight. Continental Shelf Research 30 (12): 1275-1282.

Murphy, James, and John P. Riley. 1962. A modified single solution method for the determination of phosphate in natural waters. Analytica Chimica Acta 27: 31-36.

Murphy, Cole D., Mitchell S. Roodvoets, Emily J. Austen, Allison Dolan, Audrey Barnett, and Douglas A. Campbell. 2017. Photoinactivation of photosystem II in Prochlorococcus and Synechococcus. PLoS One 12 (1): e0168991. https://doi.org/10.1371/journal.pone. 0168991.

Nicolau, Rudy, Adriana Galera-Cunha, and Yves Lucas. 2006. Transfer of nutrients and labile metals from the continent to the sea by a small Mediterranean river. Chemosphere 63 (3): 469-476.

Olson, Robert J., Erik R. Zettler, and Michele D. DuRand. 1993. Phytoplankton analysis using flow cytometry. In Handbook of methods in aquatic microbial ecology, ed. Paul F. Kemp, Barry F. Sherr, Evelyn B. Sherr, and Jonathan J. Cole, 175-186. Boca Raton: Lewis Publishers.

Palenik, Brian, Qinghu Ren, Chris L. Dupont, Garry S. Myers, John F. Heidelberg, Jonathan H. Badger, Ramana Madupu, William C. Nelson, Lauren M. Brinkac, Robert J. Dodson, A. Scott Durkin, Sean C. Daugherty, Stephen A. Sullivan, Hoda Khouri, Yasmin Mohamoud, Rebecca Halpin, and Ian T. Paulsen. 2006. Genome sequence of Synechococcus CC9311: Insights into adaptation to a coastal environment. PNAS 10 (36): 13555-13559.

Pan, Luoan, Jing Zhang, and Lihua Zhang. 2007. Picophytoplankton, nanophytoplankton, heterotrophic bacteria and viruses in the Changjiang Estuary and adjacent coastal waters. Journal of Plankton Research 29 (2): 187-197.

Partensky, Frédéric, Jean Blanchot, and Daniel Vaulot. 1999. Differential distribution and ecology of Prochlorococcus and Synechococcus in ocean waters. A review. Bulletin de l'Institut océanographique (Monaco) 19: 457-475.

Pougnet, Frédérique, Jörg Schäfer, Lionel Dutruch, Cédric Garnier, Erwan Tessier, Duc Huy Dang, Laurent Lanceleur, Jean-Ulrich Mullot, Véronique Lenoble, and Gérard Blanc. 2014. Sources and historical record of tin and butyl-tin species in a Mediterranean bay (Toulon Bay, France). Environmental Science and Pollution Research 21 (10): 6640-6651.

Ribeiro, Catherine Gérikas, Dominique Marie, Adriana Lopes dos Santos, Frederico Pereira Brandini, and Daniel Vaulot. 2016. Estimating microbial populations by flow cytometry: Comparison between instruments. Limnology and Oceanography 14 (11): 750 758.

Rossi, Nadège. 2008. Écologie des communautés planctoniques méditerranéennes et étude des métaux lourds (Cuivre, Plomb, Cadmium) dans différents compartiments de deux écosystèmes côtiers (Toulon, France). PhD Thesis, Université du Sud-Toulon Var.

Rossi, Nadège, and Jean-Louis Jamet. 2008. In situ heavy metals (copper, lead and cadmium) in different plankton compartments and suspended particulate matter in two coupled Mediterranean coastal ecosystems (Toulon Bay, France). Marine Pollution Bulletin 56 (11): 1862-1870.
Rossi, Nadège, and Jean-Louis Jamet. 2009. Structure and succession of plankton communities in two Mediterranean neighbouring coastal ecosystems (Toulon Bays, France). In New oceanography research developments, ed. Louis Martorino and Karl Puopolo, 269-282. New York: Nova Science Publishers.

Salhi, Nousseiba, Habiba Zmerli Triki, Juan Carlos Molinero, Laabir Mohamed, E. Sehli, Amel Bellaaj-Zouari, Néjib Daly Yahia, and Ons Kefi-Daly. 2017. Seasonal variability of picoplankton under contrasting environments in northern Tunisian coasts, southwestern Mediterranean Sea. Marine Pollution Bulletin. 129 (2): 866-874. https://doi.org/10.1016/j.marpolbul.2017.10.029.

Šantić, Danijela, Nada Krstulović, Mladen Šolić, and Grozdan Kušpilić. 2011. Distribution of Synechococcus and Prochlorococcus in the central Adriatic Sea. Acta Adriatica 52 (1): 101-114.

Serranito, Bruno, Anaïs Aubert, Lars Stemmann, Nadège Rossi, and Jean-Louis Jamet. 2016. Proposition of indicators of anthropogenic pressure in the Bay of Toulon (Mediterranean Sea) based on zooplankton time-series. Continental Shelf Research 121: 3-12.

Siokou-Frangou, Ioanna, Urania Christaki, Maria Grazia Mazzocchi, Marina Montresor, Maurizio Ribera d'Alcalá, Dolors Vaqué, and Adriana Zingone. 2010. Plankton in the open Mediterranean Sea: A review. Biogeosciences 7 (5): 1543-1586.

Somogyi, Boglárka, Tamás Felföldi, József Vanyovski, Ákos Ágyi, Károly Márialigeti, and Lajos Vörös. 2009. Winter bloom of picoeukaryotes in Hungary shallow turbid soda pans and the role of light and temperature. Aquatic Ecology 43 (3): 735-744.

Stockner, John G. 1988. Phototrophic picoplankton: An overview from marine and freshwater ecosystems. Limnology and Oceanography 33 (4, part 2): 765-775.

Strickland, John D.H. 1965. Phytoplankton and marine primary production. Annual Review of Microbiology 19 (1): 127-162.

Strickland, John D.H., and Tim R. Parsons. 1968. A practical handbook of seawater analysis-Determination of reactive phosphorus. Journal of the Fisheries Research Board of Canada 167: 49-56.

Talarmin, Agathe, France Van Wambeke, Philippe Lebaron, and Thierry Moutin. 2015. Vertical partitioning of phosphate uptake among picoplankton groups in the low Pi Mediterranean Sea. Biogeosciences 12 (4): 1237-1247.

Tessier, Erwan. 2012. Diagnostic de la contamination sédimentaire par les métaux/métalloïdes dans la rade de Toulon et mécanismes contrôlant leur mobilité. PhD Thesis, Université de Toulon et du Var.

Tessier, Erwan, Cédric Garnier, Jean-Ulrich Mullot, Véronique Lenoble, Mireille Arnaud, Michel Raynaud, and Stéphane Mounier. 2011. Study of the spatial and historical distribution of sediment inorganic contamination in the Toulon Bay (France). Marine Pollution Bulletin 62 (10): 2075-2086.

Thyssen, Melilotus, Gérald J. Grégori, Jean-Michel Grisoni, Maria Luiza Pedrotti, Laure Mousseau, Luis F. Artigas, Sophie Marro, Nicole Garcia, Ornella Passafiume, and Michel J. Denis. 2014. Onset of the spring bloom in the northwestern Mediterranean Sea: Influence of environmental pulse events on the in situ hourly-scale dynamics of the phytoplankton community structure. Frontiers in Microbiology 5 (387): 1-16.

Tréguer, Paul, and Pierre Le Corre. 1975. Manuel d'analyse des sels nutritifs dans l'eau de mer (utilisation de l'AutoAnalyzer II Technicon $®)$, 2ème édition. Brest: Université Bretagne Occidentale.

Uitz, Julia, Dariusz Stramski, Bernard Gentili, Fabrizio D’Ortenzio, and Hervé Claustre. 2012. Estimates of phytoplankton class-specific and total primary production in the Mediterranean Sea from satellite ocean color observations. Global Ecological Cycles 26 (2): GB2024. https://doi.org/10.1029/2011GB004055.

Vaulot, Daniel, and Frédéric Partensky. 1990. Winter presence of prochlorophytes in surface waters of the Northwestern Mediterranean Sea. Limnology and Oceanography 35 (5): 11561164. 
Veldhuis, Marcel J.W., and Gijsbert W. Kraay. 2000. Application of flow cytometry in marine phytoplankton research: Current application and future perspectives. Scientia Marina 64 (2): 121-134.

Yentsch, Clarice M., and Paul K. Horan. 1989. Cytometry in the aquatic sciences. Cytometry 10 (5): 497-499.

Yentsch, Clarice M., Paul K. Horan, Katharine Muirhead, Quay Dortch, Elin Haugen, Louis Legendre, Lynda S. Murphy, Mary Jane Perry,
David A. Phinney, Shirley A. Pomponi, Richard W. Spinrad, Michelle Wood, Charles S. Yentsch, and Bernard J. Zahuranec. 1983. Flow cytometry and cell sorting: A technique for analysis and sorting of aquatic particles. Limnology and Oceanography 28 (6): $1275-1280$. 